\title{
An Improved Approach to Characterize Potash-Bearing Evaporite Deposits, Evidenced in North Yorkshire, United Kingdom
}

\author{
S. J. Kemp, ${ }^{1, \dagger}$ F. W. Smith, ${ }^{2}$ D. Wagner, ${ }^{1}$ I. Mounteney, ${ }^{1}$ C. P. Bell, ${ }^{2}$ C. J. Milne, ${ }^{1}$ C. J. B. Gowing, ${ }^{1}$ and T. L. Pottas ${ }^{3}$ \\ ${ }^{1}$ British Geological Survey, Environmental Science Centre, Keyworth, Nottingham NG12 5GG, United Kingdom \\ ${ }_{2}^{2}$ FWS Consultants Ltd., Merrington House, Merrington Lane Industrial Estate, Spennymoor, Co. Durham DL16 7UT, United Kingdom \\ ${ }^{3}$ York Potash Ltd., 7-10 Manor Court, Manor Garth, Scarborough YO11 3TU, United Kingdom
}

\begin{abstract}
Traditionally, potash mineral deposits have been characterized using downhole geophysical logging in tandem with geochemical analysis of core samples to establish the critical potassium $\left(\% \mathrm{~K}_{2} \mathrm{O}\right)$ content. These techniques have been employed in a recent exploration study of the Permian evaporite succession of North Yorkshire, United Kingdom, but the characterization of these complex deposits has been led by mineralogical analysis, using quantitative X-ray diffraction (QXRD). The novel QXRD approach provides data on K content with the level of confidence needed for reliable reporting of resources and also identifies and quantifies more precisely the nature of the K-bearing minerals. Errors have also been identified when employing traditional geochemical approaches for this deposit, which would have resulted in underestimated potash grades.

QXRD analysis has consistently identified polyhalite $\left(\mathrm{K}_{2} \mathrm{Ca}_{2} \mathrm{Mg}\left(\mathrm{SO}_{4}\right)_{4} \cdot 2\left(\mathrm{H}_{2} \mathrm{O}\right)\right.$ in the Fordon (Evaporite) Formation and sylvite $(\mathrm{KCl})$ in the Boulby Potash and Sneaton Potash members as the principal K-bearing host minerals in North Yorkshire. However, other $\mathrm{K}$ hosts, including kalistrontite $\left(\mathrm{K}_{2} \mathrm{Sr}\left(\mathrm{SO}_{4}\right)_{2}\right)$ a first recorded occurrence in the UK, and a range of boron-bearing minerals have also been detected.

Application of the QXRD-led characterization program across the evaporitic basin has helped to produce a descriptive, empirical model for the deposits, including the polyhalite-bearing Shelf and Basin seams and two, newly discovered sylvite-bearing bittern salt horizons, the Pasture Beck and Gough seams. The characterization program has enabled a polyhalite mineral inventory in excess of 2.5 billion metric tons (Bt) to be identified, suggesting that this region possesses the world's largest known resource of polyhalite.
\end{abstract}

\section{Introduction}

Potash is a generic term which encompasses a range of potassium-bearing minerals and industrial products, which include sylvite $(\mathrm{KCl})$ and polyhalite $\left(\mathrm{K}_{2} \mathrm{Ca}_{2} \mathrm{Mg}\left(\mathrm{SO}_{4}\right)_{4} \cdot 2\left(\mathrm{H}_{2} \mathrm{O}\right)\right)$. Mining of potash probably began in the late $18^{\text {th }}$ century but exploitation rapidly accelerated following the 1840 discovery by Justus von Liebig, that potash was a nutrient for crops (Prud'homme and Krukowski, 2006).

Potassium forms one of the three essential plant nutrients (the "K" in "NPK" terminology) and as a result, 95\% of potash production is used as plant fertilizer. Potassium is critical for plant growth and disease resistance, and soil fertilization is necessary to replace that removed by cumulative plant uptake and soil processes. World population growth coupled with an increasing demand for protein-rich diets and a decreasing supply of arable land have driven increasing prices and high global demand for potash. The remaining $5 \%$ of global potash production is used by the chemical industry for a variety of products, including soaps and detergents, glass and ceramics, explosives, medicines, batteries, drilling muds, and electroplating (Adams and Hite, 1983; Prud'homme and Krukowski, 2006).

Although potassium is a major constituent of many silicate minerals found in igneous, metamorphic, and sedimentary rocks, most of the world's potash resources are found in subsurface, bedded evaporite deposits that produce high-grade, large tonnage orebodies, which afford low-cost mining and

† Corresponding author: email, sjk@bgs.ac.uk beneficiation (Prud'homme and Krukowski, 2006). These are generally believed to have developed by the evaporation of seawater (or seawater and brine mixtures) in bar-restricted marine basins. Typically a gradational precipitation occurs from the most soluble salts in the deeper parts of the basin to the least soluble salts close to the bar, producing a tabular deposit with lateral facies changes.

Little information is provided in the peer-reviewed literature concerning the characterization of potash deposits. However, a number of published technical reports by mining professionals provide more insight into their evaluation and grade determinations. Potash deposits have most often been assessed using a combination of onsite downhole geophysical logging (Prud'homme and Krukowski, 2006; Nelson, 2007; Crowl et al., 2011) combined with offsite assay using core samples and laboratory geochemical analyses by inductively coupled plasma-atomic emission spectroscopy (ICP-AES or optical emission spectroscopy (OES), e.g., Lomas, 2008; Hardy et al., 2010; SRK Consulting, 2011; SRK Consulting et al., 2012) or less frequently X-ray fluorescence spectrometry (XRFS, laboratory, e.g., Crowl et al., 2011; hand-held, e.g., Eccles et al., 2009) techniques to establish their potassium content $\left(\% \mathrm{~K}_{2} \mathrm{O}\right)$. Operating $\mathrm{KCl}$ mines also employs a sodium tetraphenylboron (STPB) titration technique (International Fertilizer Industry Association, 2009). Such geochemical analyses, while providing the valuable total or soluble potassium content, do not identify the precise mineralogical nature and concentration of the potassium-bearing mineral host(s). This is of critical importance since many deposits have a complex 
mineralogy resulting from replacement and hydration reactions, selective dissolution, and other mechanisms that have significantly modified their original composition. Despite this, some explorationists continue to rely upon complicated systems of recalculating mineralogy from elemental analysis in combination with detailed core logging, and this can lead to errors in identification.

The polyhalite deposits of North Yorkshire are so high grade that they can be mined and marketed with no processing except crushing and sizing. It is of unusually high importance, therefore, to be certain of their mineralogical composition and the accurate polyhalite content.

Mineralogical techniques such as X-ray diffraction (XRD) analysis have rarely been employed in potash characterization and grade determination projects and only then as a qualitative, mineral identification tool (e.g., Rauche and van der Klauw, 2007, 2010; Crowl et al., 2011). XRD has generally been regarded by explorationists as a slow, expensive, and therefore superfluous technique. However, modern developments in XRD analysis, in terms of hardware (ultrahighspeed detector technology, automation) and software (search, match, identify routines, and digital databases) have accelerated analytical throughput, particularly in mineral quantification techniques. Through the application of the Rietveld methodology (Rietveld, 1969; Bish and Post, 1993), XRD can now provide a precise and accurate means of assay that can provide a cost-effective solution for many mineral exploration and processing programs.

This paper outlines the mineralogical characterization and grade determination of potash-bearing deposits from North Yorkshire and the use of quantitative X-ray diffraction (QXRD) analysis as the principal assay method for borehole core material. Complimentary petrographic and isotopic studies and a description of the genesis and evolution of the deposit will be covered in a future paper.

Introductory overviews of geophysical logging, traditional potash assay, and XRD analysis are included below.

\section{Geophysical logging}

Many of the world's potash deposits were discovered during hydrocarbon exploration activities and their mineralogical characterization and grade determination has often benefitted from the availability of comparative borehole geophysical data obtained from gamma ray, neutron, sonic, caliper, density, and resistance logs (Prud'homme and Krukowski, 2006). The geophysical evidence is all the more valuable as the deposits were rarely cored and thus frequently lack mineralogical data.

Wireline spectral gamma-ray tools provide particularly useful onsite indications of evaporite lithology, stratigraphy, and formation mineralogy (Alger and Crain, 1966; Crain and Anderson, 1966; Tixier and Alger, 1970). The total gammaray spectra, measured in counts per second (cps), is resolved into the three most commonly encountered components of naturally occurring radiation in sedimentary successionspotassium $\left({ }^{40} \mathrm{~K}\right)$, uranium $\left({ }^{238} \mathrm{U}\right)$, and thorium $\left({ }^{232} \mathrm{Th}\right)$. In hydrocarbon exploration, the spectral gamma tool is therefore frequently used to identify and discriminate clay-rich lithologies from sandstones or limestones. In addition, the shape of the gamma-ray log may be used to reconstruct downhole fluctuations in grain size, and infer changes in sedimentary facies: the standard approach is to interpret bell-shaped gamma curves as a fining-upward sequence and funnel-shaped gamma curves as a coarsening-upward sequence (Serra and Sulpice, 1975). However, these methods are only relevant to simple sandstone/shale formations and are subject to error where a significant sand fraction is present, for example, feldspars contain more K than micas (Humphreys and Lott, 1990; Rider, 1990).

In potash deposits, $\mathrm{U}$ and $\mathrm{Th}$ provide a minimal component of the total radioactivity and the typically percent values of $\mathrm{K}$ present can be readily measured. In oil and gas well logging, gamma-ray response is measured in American Petroleum Institute (API) units, established in a calibration facility in Houston, Texas (Belnap et al., 1959). Typical API unit values for pure K-bearing minerals are shown in Table 1 and compare to the zero values obtained for the most prevalent gangue minerals, halite and anhydrite.

API units may then be converted to an equivalent $\mathrm{K}$ concentration (equiv $\mathrm{K}_{2} \mathrm{O} \%$ ), a reasonable indirect representation of the in situ potash $\left(\mathrm{K}_{2} \mathrm{O}\right)$ grade. Such equiv $\mathrm{K}_{2} \mathrm{O} \%$ data have been used for in situ potash determinations since the 1960s (e.g., Alger and Crain, 1966; Hardy et al., 2010; Yang and Chi, 2013). For example, Hardy et al. (2010) obtained a $92 \%$ correlation between the gamma-derived equiv $\mathrm{K}_{2} \mathrm{O} \%$ and inductively coupled plasma (ICP) derived results. However, errors arise in such grade determinations as "tails" of gamma radiation, measured from adjacent beds, are included in borehole measurements. As a consequence, a plot of borehole gamma-ray activity versus radioactivity measured from core materials can exhibit considerable scatter (Nelson, 2007). Further grade determination errors may arise due to depth misalignment, excessive logging speed, gamma-ray attenuation due to cement, casing or mud weight, washouts, thin beds, inappropriate drilling muds, or the presence of $\mathrm{U}$ and/ or Th (Nelson, 2007).

Consideration of gamma, sonic, neutron, and density logs as a suite provides the ability to identify mineral species. Monomineralic deposits are particularly easy to resolve. Mixed deposits become increasingly difficult, although attempts have been made in the past to resolve the complex mineralogy such as that found in the Fordon (Evaporite) Formation into varying proportions of anhydrite, polyhalite, halite, and kieserite using linear programming techniques (Ford et al., 1974).

\section{Traditional potash assay}

Traditionally, potash deposits have been assayed using elemental analysis techniques to determine concentrations of

Table 1. Gamma-ray Response to K-Bearing Minerals (adapted from Edmundson and Raymer, 1979)

\begin{tabular}{llcc}
\hline \hline Mineral & Chemical formula & $\mathrm{K}_{2} \mathrm{O}($ wt \%) & API units \\
\hline Carnallite & $\mathrm{KMgCl} \cdot 6 \mathrm{H}_{2} \mathrm{O}$ & 17.0 & 200 \\
Kainite & $\mathrm{KMg}\left(\mathrm{SO}_{4}\right) \mathrm{Cl} \cdot\left(\mathrm{H}_{2} \mathrm{O}\right)_{2.75}$ & 18.9 & 229 \\
Kalistrontite & $\mathrm{K}_{2} \mathrm{Sr}\left(\mathrm{SO}_{4}\right)_{2}$ & 26.3 & 303 \\
Langbeinite & $\mathrm{K}_{2} \mathrm{Mg}_{2}\left(\mathrm{SO}_{4}\right)_{3}$ & 22.7 & 268 \\
Picromerite & $\mathrm{K}_{2} \mathrm{Mg}\left(\mathrm{SO}_{4}\right)_{2} \cdot 6\left(\mathrm{H}_{2} \mathrm{O}\right)$ & 23.4 & 287 \\
Polyhalite & $\mathrm{K}_{2} \mathrm{Ca}_{2} \mathrm{Mg}\left(\mathrm{SO}_{4}\right)_{4} \cdot 2\left(\mathrm{H}_{2} \mathrm{O}\right)$ & 15.6 & 185 \\
Sylvite & $\mathrm{KCl}$ & 63.2 & 747 \\
\end{tabular}


$\mathrm{K}$ and other major elements (typically $\mathrm{Mg}, \mathrm{Na}, \mathrm{Ca}, \mathrm{S}$, and sometimes $\mathrm{Cl}$ ). The data may be expressed as equiv $\mathrm{K}_{2} \mathrm{O} \%$ or be used to infer mineralogies from calculated stoichiometric combination of elements, but for complex samples this may not be sufficient to establish the mineral phases unequivocally.

Although the techniques used for the final determination of quantitative elemental analysis vary and have evolved with developments in instrumentation (from flame photometry through atomic absorption to modern ICP-AES and even ICP-MS), the wet chemistry techniques used to prepare samples for analysis are more classic and have been established for many years. Simple aqueous dissolutions can be used to determine the soluble mineral fraction, often accompanied by a gravimetric determination of insoluble residue. This approach has been adopted for several major potash resource investigations within the last decade, using measurement by ion chromatography (IC, Rauche and van der Klauw, 2007) or by ICP-AES (Hardy et al., 2010), for example. For sylvite-rich potash deposits this can be effective. Indeed, the combination of aqueous leaching of soluble phases with ICP-AES analysis still forms the basis of some major commercially available analytical potash exploration packages today (e.g., Saskatchewan Research Council, Saskatoon, 2015), but crucially these are not suited for the determination of insoluble potash minerals, notably including polyhalite.

In order to determine $\mathrm{K}$ in polyhalite, or other metals contained in insoluble and silicate phases a more aggressive preparation is required. Two such approaches are widely used: acid digestion and high-temperature fusion. Mixed acid digestions based on hydrofluoric and perchloric acids have been advocated for many decades (e.g., Morgan, 1921) and acid digestions have been applied during potash resource assessments. For example, Lomas (2008) used both an aqua regia (nitric and hydrochloric acid mixture) "partial" digestion and a four-acid "total" digestion, both with an ICP-AES finish. Crowl et al. (2011) similarly applied both aqua regia and four-acid digestions $\left(260^{\circ} \mathrm{C}\right)$ with ICP-AES but observed underreporting of $\mathrm{K}, \mathrm{Ca}, \mathrm{Mg}$, and $\mathrm{Sr}$ for standard reference materials. Better results were obtained when they changed to a high-temperature lithium metaborate fusion technique in combination with ICP-AES (the fused material is taken into solution prior to analysis). The fusion approach to the breakdown of insoluble samples, typically using lithium metaborate as a flux, is also well-established being widely used to prepare fused glass beads of geologic materials for XRFS analysis. It can provide good sample homogeneity with complete dissolution. However, fusion also has limitations, with the possibility that more volatile elements can be lost during the high-temperature fusion stage.

XRFS provides a strong alternative analytical approach to ICP. Analysis of fused glass beads is usually regarded as offering the best precision for major elements, but XRFS can also be applied to dry pulped or pressed-pellet samples, for example, as part of the suite of techniques deployed for potash analysis by Crowl et al. (2011). The element suites for these techniques vary from laboratory to laboratory, so although Crowl et al. (2011) used a separate gravimetric barium precipitation technique to determine $\mathrm{S}$, some laboratories are able to offer $\mathrm{S}$ as part of an ICP-AES or XRFS suite.

\section{X-ray diffraction analysis}

Since the first experiments on a single crystal by von Laue in 1912 (Eckert, 2012), X-ray diffraction has been critical to advancing the understanding of the structure of crystalline matter on an atomic scale, including the pioneering work on penicillin (Crowfoot et al., 1949) and DNA (Watson and Crick, 1953). In the geologic sciences, the powder diffraction method allowed the unambiguous identification of minerals for the first time, particularly those beyond the resolution of a petrographic microscope. A comprehensive database (International Centre for Diffraction Data, 2014) and computer-based search-match techniques have developed over the subsequent years.

QXRD analysis has proved more difficult to achieve. Early methods relied on obtaining suitable physical, "standard" minerals from which synthetic mixtures were produced. XRD scans of such mixtures created single peak height/area calibration curves. Unfortunately, many naturally occurring minerals show solid-solution series (e.g., silicates) and differences in crystallinity (e.g., phyllosilicates and clay minerals) that make accurate matching with mineral standards impossible with a causative loss of quantification accuracy. Further problems with preferred orientation and peak overlap exacerbated the deficiencies.

More effective and accurate quantification was promised by the "standardless" Rietveld analysis first developed in the 1960s (Rietveld, 1969; Snyder and Bish, 1989; Degen et al., 2014). This methodology employs the total diffraction pattern coupled with the crystal structure data (e.g., Inorganic Crystal Structural Database, 2014) for the identified, constituent phases and involves a least-squares refinement process that matches and refines the crystal structural data to the sample pattern. Variations in mineral chemistry, crystallinity, and problems associated with XRD peak overlap and preferred orientation can be readily accommodated. Initially, the method used analytic functions to describe the diffraction peak shapes and was slow and very unstable. However, modern software has greatly improved stability and the peak profiles are now calculated from first principles, giving much better and more rapid descriptions of the measured peak profiles.

In order to compare the sample diffraction pattern with one calculated from known crystal structure data, Rietveld refinement requires the following:

1. A high-resolution XRD pattern with low background and high diffraction peak intensities. Such patterns are now rapidly achievable using modern X-ray detectors.

2. Knowledge of "fundamental" parameters, such as goniometer radius and slit sizes in order to calculate the instrumental input to diffraction peak profile shapes. These parameters are required to separate the instrumental and sample effects on the diffraction pattern.

3. All phases present in the sample are identified and phase specific parameters are available for each of these, including unit cell and space group, atomic parameters, and ideally, the compositions of solid-solution phases (e.g., silicates, carbonates, clay minerals, etc.).

Accurate quantitative results from Rietveld analysis are wholly reliant on the quality of the primary diffraction data produced. Samples must be uniformly ground to a fine-particle 
size (typically $<5 \mu \mathrm{m}$ ) and ideally be randomly presented to the X-ray beam. The diffractometer must also be accurately aligned to allow identification of all constituent phases.

The adoption of improved sample preparation, analytical hardware, and Rietveld techniques have recently brought about a dramatic improvement in the precision (e.g., Stutzman, 2005) and accuracy (e.g., Omotoso et al., 2006) of QXRD analyses.

Although excellent results are now within reach, the amount of effort and expertise required to achieve accurate and precise QXRD analysis should not be underestimated (Madsen et al., 2001). Scrutiny of the results from the "Reynolds Cup," the biennial, quantitative mineralogy round-robin (Raven and Self, 2013), indicates a steady, overall improvement in accuracy from 2000 to present. However, results are variable, as while some laboratories consistently achieve excellent results, some participants continue to struggle. The effort required to produce accurate QXRD analyses on small batches of samples may generate a price penalty compared to routine, geochemical analysis. However, where larger batches of analyses are required, increased levels of automation mean that QXRD pricing is cost effective, particularly considering the additional information gained.

Such improvements mean that XRD is increasingly playing a critical role in mineral deposit and processing evaluation (e.g., Hestnes and Sørensen, 2012; Knorr, 2012; Allen et al., 2013; Santini, 2015). For example, Knorr (2012) described how XRD can be used in iron ore mining, to explain severe recovery losses. Yield estimates are typically based on chemical analysis but iron may be locked in minerals that are removed during the beneficiation, or which are inaccessible to the extraction process. Such carrier minerals could be gibbsite or ferrous dolomite/ankerite. Chemical analysis does not determine the mineral hosts, whereas a simple XRD peak-position analysis can determine the amount of nonextractable iron. Hestnes and Sørensen (2012) recommended a dual Rietveld XRD and XRF approach for onsite quality-control management in processing quartz and feldspar products derived from a granitic pegmatite.

QXRD therefore has considerable potential to provide both the mineralogical and grade determinations necessary for potash deposit exploration projects.

\section{York Potash deposit and geology}

The Permian evaporite succession of North Yorkshire, UK, has been exploited since the late 1960s for its valuable potash resource, primarily for agricultural fertilizer but with an important by-product of rock salt (halite, $\mathrm{NaCl}$ ), used for deicing roads in winter conditions. Historically mining activity has been focussed at the Boulby mine, between Redcar and Whitby, and worked the Boulby Potash Member for its sylvite (KCl) content (Fig. 1). Current output is about $1 \mathrm{Mt} / \mathrm{ann}$. of refined $\mathrm{KCl}$ product and 0.6 Mt of road salt. The Boulby

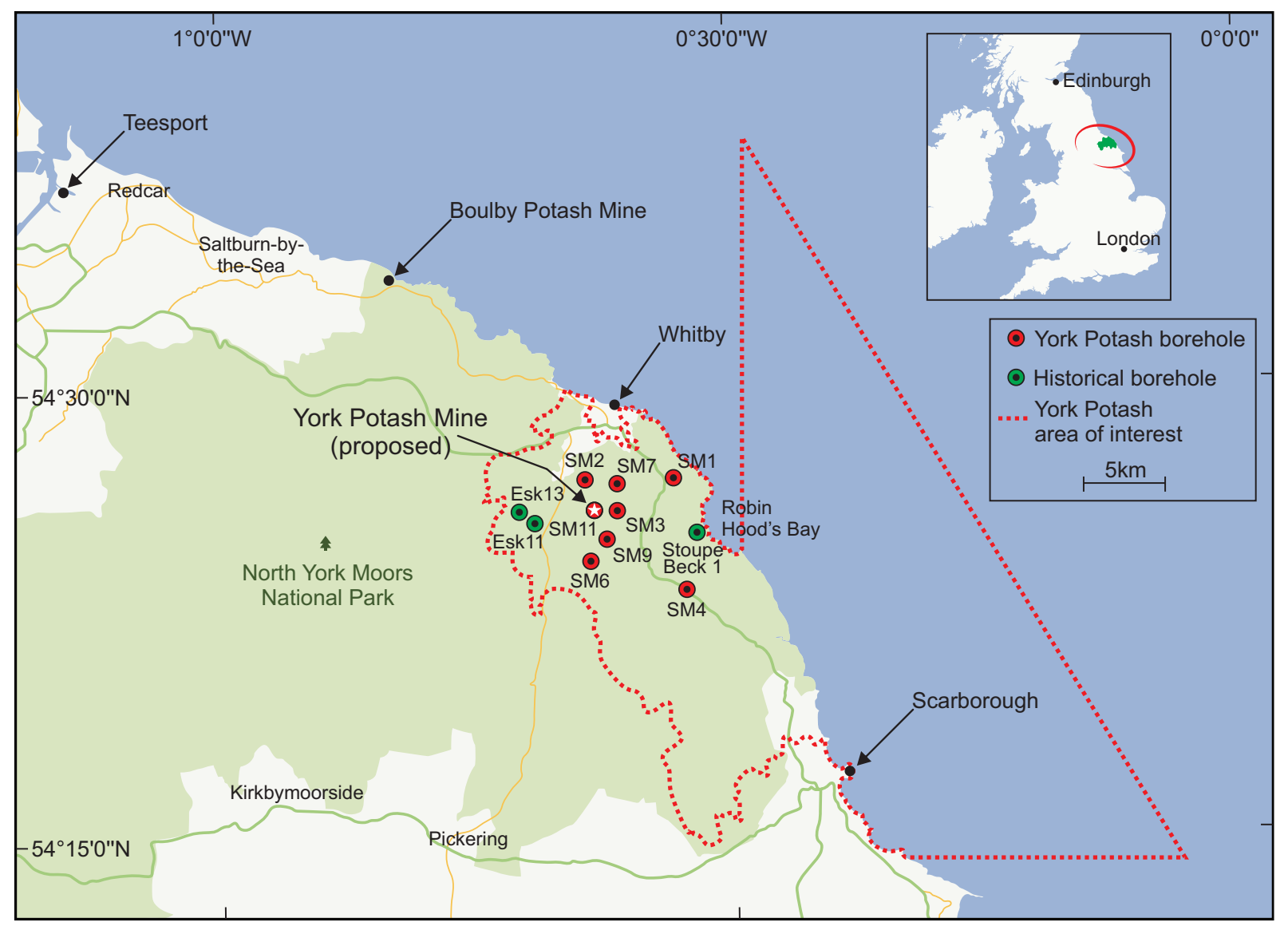

Fig. 1. Map indicating the York Potash area of interest (AOI) and location of the exploration and historical boreholes examined in this study. 
mine is the sole indigenous potash source supplying $55 \%$ of the total UK market (British Geological Survey, 2011).

Although originally discovered in 1939, the deeper, polyhalite $\left(\mathrm{K}_{2} \mathrm{Ca}_{2} \mathrm{Mg}\left(\mathrm{SO}_{4}\right)_{4} \cdot 2\left(\mathrm{H}_{2} \mathrm{O}\right)\right)$-bearing Fordon (Evaporite) Formation was largely overlooked until recently. However, recognition of the potential value of polyhalite as a slow-release, multielement fertilizer lacking chloride has rekindled interest, and it is now being actively explored underground at the Boulby mine, by ICL Fertilizers; and from surface, farther south, by York Potash Ltd. (a subsidiary of Sirius Minerals, Plc).

The recent surface exploration program by York Potash Ltd. between Whitby and Scarborough (Fig. 1) consisted of over $16 \mathrm{~km}$ of deep drilling and $4.2 \mathrm{~km}$ of coring, to depths of $1.7 \mathrm{~km}$, and the reprocessing and reinterpretation of $2,300 \mathrm{~km}$ of on- and offshore seismic surveys. Indications from these suggest that the Fordon (Evaporite) Formation in this region contains the world's largest known resource of polyhalite (Smith et al., 2014).

Five evaporite cycles (EZ1-EZ5) are developed in the northwestern corner of the main Permian Zechstein basin where it comes onshore in the UK between Teesside and Lincolnshire (Fig. 2). The relationship between the evaporite sequence in the main basin and its onshore, lateral gradation into shelf and then semicontinental clastic strata was described by Smith (1989). Potash salts are known from cycles EZ2, EZ3, and EZ4, and Britain's only potash producer, the Boulby mine, exploits sylvite from the EZ3 Boulby Potash Member. Sylvite-bearing horizons are also known in the EZ2 cycle, but the principal potash resource therein is polyhalite, first discovered in 1939 in the E2 oil exploration hole at Eskdale, Whitby (Stewart, 1949). The only known occurrence of polyhalite in the UK is in the EZ2 Fordon (Evaporite) Formation in this area. Although polyhalite is not an uncommon minor component of potash-bearing evaporites (e.g., Peryt et al., 1998, and references therein), it is extremely unusual to find it in potentially mineable quantity and quality.

Mineral zonation in the Fordon (Evaporite) Formation was first described in detail by Stewart $(1949,1963)$ from the

\begin{tabular}{|c|c|c|l|}
\hline $\begin{array}{c}\text { Zechstein } \\
\text { cycle }\end{array}$ & \multicolumn{3}{|c|}{ North East England onshore lithostratigraphy } \\
\hline EZ5 & $\begin{array}{c}\text { Eskdale } \\
\text { Group }\end{array}$ & $\begin{array}{c}\text { Littlebeck (Anhydrite) Fm. } \\
\text { Sleights (Siltstone) Fm. }\end{array}$ & \\
\hline EZ4 & $\begin{array}{c}\text { Staintondale } \\
\text { Group }\end{array}$ & $\begin{array}{c}\text { Sneaton (Halite) Fm. } \\
\text { Sherburn (Anhydrite) Fm. } \\
\text { Upgang (Limestone) Fm. } \\
\text { Carnallitic Marl Fm. }\end{array}$ & Sneaton Potash Mbr \\
\hline EZ3 & $\begin{array}{c}\text { Teesside } \\
\text { Group }\end{array}$ & $\begin{array}{c}\text { Boulby (Halite) Fm. } \\
\text { Billingham (Anhydrite) Fm. } \\
\text { Brotherton (Mg limestone) Fm. } \\
\text { Grauer Salzton }\end{array}$ & Boulby Potash Mbr \\
\hline EZ2 & $\begin{array}{c}\text { Aislaby } \\
\text { Group }\end{array}$ & $\begin{array}{c}\text { Fordon (Evaporite) Fm. } \\
\text { Kirkham Abbey (Limestone) Fm. }\end{array}$ & \\
\hline EZ1 & $\begin{array}{c}\text { Don } \\
\text { Group }\end{array}$ & $\begin{array}{c}\text { Hayton (Anhydrite) Fm. } \\
\text { Cadeby (Limestone) Fm. } \\
\text { Marl Slate Fm. }\end{array}$ & \\
\hline
\end{tabular}

Fig. 2. Permian lithostratigraphical units in northeastern England (after Smith et al., 1986), exploration targets are shown shaded. EZ = English Zechstein units.
Eskdale and Fordon boreholes. Polyhalite was described as partly primary but mostly a replacement of primary anhydrite. Three subcycles were recognized at Fordon. The Lower subcycle was deposited in a basin that still displayed considerable topographic variation from a shallow-water shelf to a deepwater basin. It contains no known potash occurrences. The Middle subcycle, in which the polyhalite occurs, includes a large volume of basin-fill evaporites, chiefly halite, that filled and smoothed out the shelf-basin geometry. Consequently it shows considerable variation in thickness. The Upper subcycle formed in uniformly shallow-water conditions with no clear distinction between shelf and basin. It hosts a persistent sylvite-bearing horizon. Colter and Reed (1980) showed that Stewart's mineral zones could be projected far beyond the Fordon borehole and were recognizable throughout much of the British section of the North Sea basin (Doornenbal and Stevenson, 2010).

Between 2011 and 2014, the exploration project of York Potash Ltd. focused on the polyhalite-bearing Fordon Middle subcycle between Eskdale, Whitby, and Scarborough (Fig. 1). Eight boreholes and eight satellite holes (deflections from the mother wells) were drilled and cored through the Fordon sequence to depths up to 1,700 $\mathrm{m}$ and also cored through most of the overlying EZ3 and EZ4 cycles (Fig. 13). The prospecting area straddles shelf facies, the basin margin ramp, and part of the deep-water basin. The description of mineral zones at Eskdale and Fordon by Stewart $(1949,1963)$ relate to boreholes drilled through the shelf and basin, respectively. The precise correlation of the polyhalite-bearing sulfate deposits between these two environments, or zones, remains ambiguous. At the present time the deposit is referred to as the Shelf seam in the Shelf zone, and Basin seam in the Basin zone, with a Transition zone across the ramp and in its vicinity where great thicknesses of polyhalite and anhydrite occur with varying amounts of early diagenetic, displacive halite. In borehole SM2 there was very strong evidence for overlapping Shelf and Basin seams, separated by $82 \mathrm{~m}$ of "sulphatic halite". Both polyhalite seams are considered to be of mineable thickness and grade in their relevant sectors of the York Potash Limited's Resource Area, averaging over $12 \mathrm{~m}$ in thickness for high grade sections of $>85 \%$ polyhalite (SRK Consulting, 2014). It is currently believed that the polyhalite is almost entirely secondary, resulting from replacement reactions between freshly deposited anhydrite muds on the sea bed, with dense, bottom flowing, $\mathrm{K}-\mathrm{Mg}$-rich brines.

A sylvite-bearing bittern salt horizon is locally present near the top of the Middle subcycle in both the Basin and the Shelf (though less commonly) and is referred to here as the Pasture Beck seam, after the borehole (also known as SM1) where it was first cored and characterized.

Another sylvite-bearing bittern salt horizon is more commonly present near the top of the Upper subcycle in both Basin and Shelf and is referred to here as the Gough seam; named after the borehole ${ }^{1}$ (also known as SM4) where it was first cored and characterized as containing relatively high

1 The Gough borehole site was named in memorial to Peter Gough (19211994), founding member and team leader of Scarborough and District Search and Rescue Team. 
grade sylvite. It is not clear why this and the Pasture Beck seam are so localized and patchy in distribution, but they may result from bittern brine pools of limited area, cut off from each other as the basin filled up at the end of each subcycle.

\section{Exploration strategy}

Since there was no established market for polyhalite in 2010 , it was of vital importance to characterize the deposit in detail to understand how a commercially valuable product would be created and what its composition was likely to be. Additionally, all the usual factors entailed in generating a geologic model, such as understanding the lateral continuity of thickness, mineralogical composition and grade, the geologic structure, and other factors affecting minability, required attention. The likely replacive nature of the deposit meant that a genetic model was also needed to assist understanding and predicting the vertical and areal extent, and the lateral continuity of the high-grade polyhalite. An understanding of the controlling mechanism was also essential to aid an awareness of likely risks of anomalous areas where replacement might have been incomplete or absent.

Legacy borehole data were reinterpreted to generate a polyhalite exploration target in York Potash Ltd.'s area of interest in 2011. This was followed by exploration drilling at sites chosen to step out from legacy well sites, and later selected to provide further data in the high-grade area, just south of Whitby. The boreholes were cored throughout almost the entire Zechstein sequence from the Littlebeck (Anhydrite) Formation through the Fordon (Evaporite) Formation and into the Kirkham Abbey Formation. Each borehole was wireline logged. Initially, geologic logging of the cores was hampered by the lack of visual distinction between the polyhalite and host anhydrite. A hand-held gamma-ray logger was used to identify the polyhalite-bearing intervals in the core.

Mineralogical characterization of the polyhalite-bearing core samples was carried out using QXRD. ICP-AES geochemistry was also employed to provide additional confidence. Sylvite seam intersections in the EZ3 and EZ4 cycles, were analyzed by conventional potash assay techniques. In addition, the newly discovered EZ2 cycle Gough and Pasture Beck seams were characterized by QXRD. Petrographic analysis of polished thin sections was also carried out on core samples selected throughout the polyhalite deposits, as an aid to understanding the complex diagenetic mineralogical transformations that have taken place, and thus aid genetic modeling.

QXRD analysis was performed on a total of 1,295 samples from eight of York Potash Ltd.'s exploration boreholes: SM1 (Pasture Beck, NZ 93587 07066), SM2 (Howlet Hall, NZ 88424 06841), SM3 (Raikes Lane, NZ 90314 04861), SM4 (Gough Juggerhowe, NZ 94613 00188), SM6 (Newton House Plantation, NZ 88670 01660), SM7 (Mortar Hall, NZ 89989 06830), SM9 (May Beck, NZ 89711 03121), SM11 (Dove’s Nest, the proposed mine site, NZ 89319 05336) including six, approximately 50-m offset cores (SM3A, SM7A, SM9A, SM9B, SM11A, and SM11B). These analyses were supplemented by analysis of an additional 73 samples from historic boreholes (Fig. 1): Eskdale 11 (NZ 85445 04302), Eskdale 13 (NZ 84920 05240), and Stoupe Beck 1 (NZ 95350 03533) held by the British Geological Survey. Where a rapid mineralogical identification was required to aid logging, the mineralogy of an additional 20 samples was evaluated using a simpler, qualitative XRD approach.

\section{Methodology}

\section{Borehole logging}

A suite of geophysical tools including Schlumberger's Hostile Environment Natural Gamma Ray Sonde (HNGS), along with density and sonic logs, were run in the York Potash Ltd. exploration boreholes. The HNGS probe is about $5 \mathrm{~cm}$ in diameter and about $1 \mathrm{~m}$ in length and contains twin sodium iodide (NaI) crystal detectors to provide increased sensitivity and faster logging. The temperature rating of this tool (up to $260^{\circ} \mathrm{C}$ ) means that it is suitable for operation in deep and hot, borehole environments such as those encountered in this investigation. The logging system consists of a winch mechanism (which controls the movement of the probe in and out of the hole) and the digital data collection device (which interfaces with a portable computer and collects the radiometric data as cps at defined intervals in the hole). Data were typically produced at approximately $1-\mathrm{cm}$ intervals as the sonde was inserted or extracted from the borehole.

The HNGS radiometric data were corrected, where necessary, to account for water in the hole (water factor), which depresses the gamma response, the instrumentation lag time in counting (dead time factor), and corrections for reduced signatures when the readings are taken inside casing (casing factor) and delivered as $\% \mathrm{~K}, \% \mathrm{U}$ and $\% \mathrm{Th}$ in API units. The manufacturers claim an accuracy of $\pm 0.5 \% \mathrm{~K}$ and a repeatability of $0.14 \%$ (Schlumberger, 2004).

\section{Core characterization}

Borehole cores from intervals of interest were transported from the drill sites to the National Geoscience Data Centre at the British Geological Survey, Keyworth, where they were dry-slabbed (to preserve any water sensitive minerals and textures). The slabbed cores were then photographed using a Phase One P65, 65mp camera, bolted to a Guardian Archive stand. The cores were flash lit with an aperture of f22 to gain full depth of field with a shutter speed of $1 / 60$ sec. Images were then processed in Phase One Capture 7 software (e.g., Fig. 3). The slabbed cores were logged by visual examination, aided by a hand-held gamma spectrometer (GMS310 Core Gamma Logger, John Caunt Scientific Ltd.). Whereas the fabrics and mineralogy of the Sneaton and Boulby sylvite seams matched well with those previously described from historic boreholes and from the Boulby mine, those observed in the polyhalite deposits were frequently uncertain and previously undescribed. Complex mineralogical intergrowths, nodules or inclusions, replacements, and overprinted fabrics were observed and recorded.

\section{Sample preparation}

Following geologic logging, one half of the core was then reslabbed and a quarter core archived in the British Geological Survey collections. A half core was returned to York Potash Ltd., and the remaining quarter core was broken up for analysis, typically in lengths varying from 0.2 to $1 \mathrm{~m}$, chosen to 


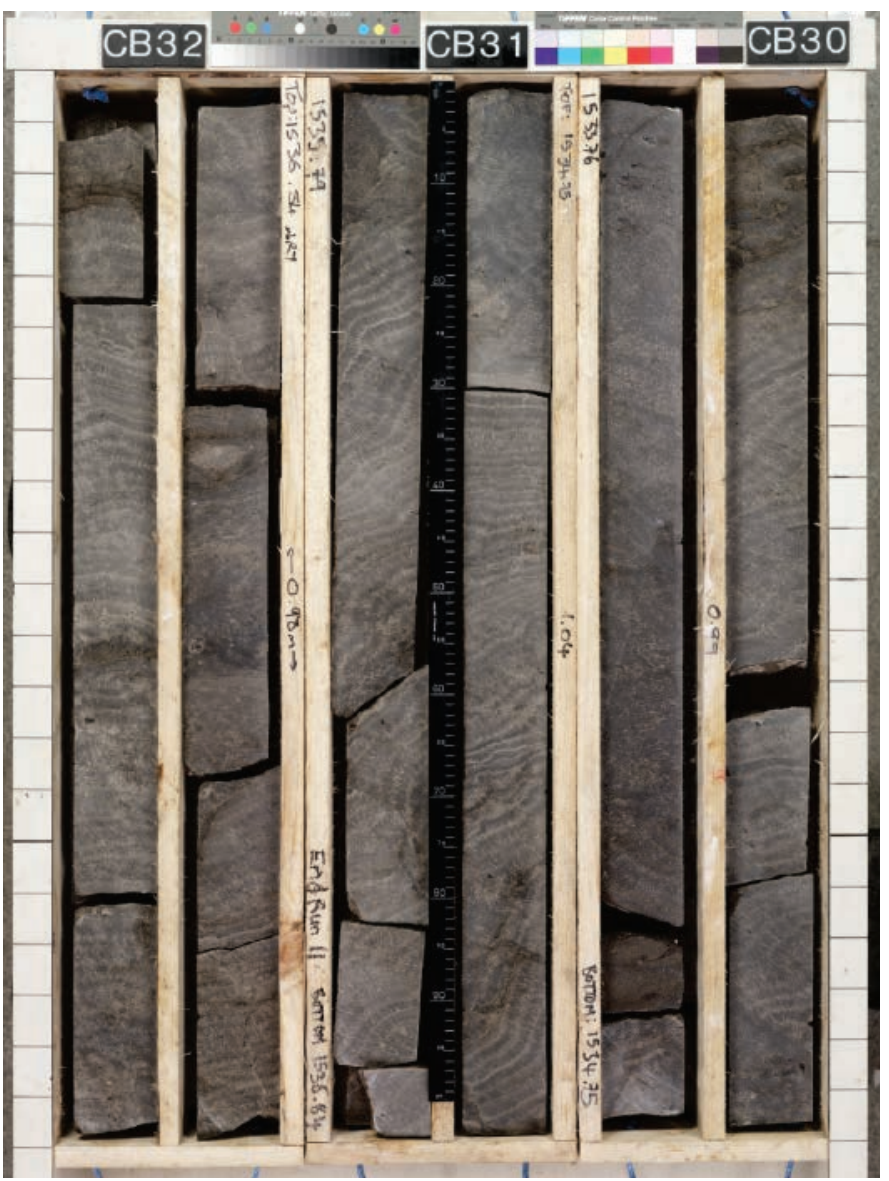

Fig. 3. Example photograph of slabbed core, showing contorted bedding of banded polyhalite with magnesite and anhydrite, $~ 1,535 \mathrm{~m}$, borehole SM3A. Scale at the side of the core is in 5 -cm intervals.

reflect changes in visible rock fabric or mineralogy, or wireline characteristics.

Samples for analysis were dried at $40^{\circ} \mathrm{C}$ overnight, and then jaw-crushed to $\sim 4$-mm diam. The crushate was then ball-milled (using agate vessels to minimize contamination) to produce a fine powder and representatively subsampled for analysis.

Analytical schedules were determined by deposit type. The sylvite-bearing seams were tested by standard procedures used by the potash industry, backed up by XRD analysis of cores through newly discovered seams. In the case of polyhalite seams, it was necessary to carry out full mineralogical analysis, supported by chemical analysis to provide additional confirmation of grade.

Accurate QXRD analysis is critically reliant on the quality of sample preparation (e.g., Bish and Reynolds, 1989). In particular, samples must (1) be uniformly ground to a very fine particle size (typically $<5 \mu \mathrm{m}$ ), (2) include an internal standard to validate the quantification results and allow the detection of any amorphous species present, and (3) be randomly presented to the X-ray beam.

It was therefore necessary to further reduce the particle size of the ball-milled powders, without subjecting the samples to either excess grinding time (which may result in crystal lattice dislocation) or excess temperature (which may cause mineral dehydration). As demonstrated by O'Connor and Chang (1986), wet micronizing in a McCrone micronizing mill presents the most apposite sample preparation method for powder XRD analysis and results in a fine and narrow grain-size distribution without damage or alteration to the mineral assemblage.

Subsamples of the ball-milled material were micronized under acetone for 10 min with $10 \%$ corundum (American Elements-PN:AL-OY-03-P) using a McCrone micronizing mill. Corundum was selected as a suitable internal standard as its principal XRD peaks are suitably remote from those produced by most of the phases present in the sample. Importantly, the mass absorption coefficient of corundum is also similar to those produced by the principal potash minerals, certainly compared to other available internal standards (Snyder and Bish, 1989). The samples were then dried at $40^{\circ} \mathrm{C}$, disaggregated in an agate pestle and mortar, and back-loaded into a standard stainless steel sample holder to provide a random orientation for analysis. At the British Geological Survey, XRD samples are routinely spray-dried (Hillier, 1999) in order to achieve a random orientation and the best possible quantification results (e.g., Breward et al., 2015). However, the temperature-sensitive nature of many of the minerals present in the potash samples precluded the elevated temperatures required to expedite the spray-drying process.

\section{$X$-ray diffraction $(X R D)$}

XRD analysis was carried out using a PANalytical X'Pert Pro series diffractometer equipped with a cobalt target tube, $\mathrm{X}^{\prime}$ Celerator detector, and operated at $45 \mathrm{kV}$ and $40 \mathrm{~mA}$. Samples were scanned from $4.5^{\circ}$ to $85^{\circ} 2 \theta$ at $2.06^{\circ} 2 \theta / \mathrm{min}$. Diffraction data were initially analyzed using PANalytical X'Pert HighScore Plus software coupled to the latest version of the International Centre for Diffraction Data database.

Following identification of the mineral species present in each sample, mineral quantification was achieved using the Rietveld refinement technique using PANalytical HighScore Plus software and reference files from the Inorganic Crystal Structural Database. Errors for the quoted mineral concentrations, calculated from synthetic mixtures of minerals relevant to this investigation, are better than $\pm 1 \%$ for concentrations $>50$ wt $\%, \pm 5 \%$ for concentrations between 50 and 20 wt $\%$ and $\pm 10 \%$ for concentrations $<10$ wt $\%$.

Details of the other analytical methodologies are included in the Appendix.

\section{Results}

Initial geologic logging of the slabbed cores (Fig. 3) and wireline geophysical logging suggested that the mineralogy of the evaporite deposits was likely to be complex.

Laboratory XRD analysis for samples from the Fordon (Evaporite) Formation, the Boulby Potash and Sneaton Potash members and the Gough and Pasture Beck seams typically produced complex profiles with "forests" of overlapping peaks (e.g., Figs. 4, 5). Interpretation of these profiles using stateof-the-art peak extraction and search/match routines coupled to the latest international standard data confirmed that the samples contain a complex and extensive range of minerals.

The major mineral species identified included polyhalite, halite, anhydrite, magnesite and, in two boreholes, kalistrontite 


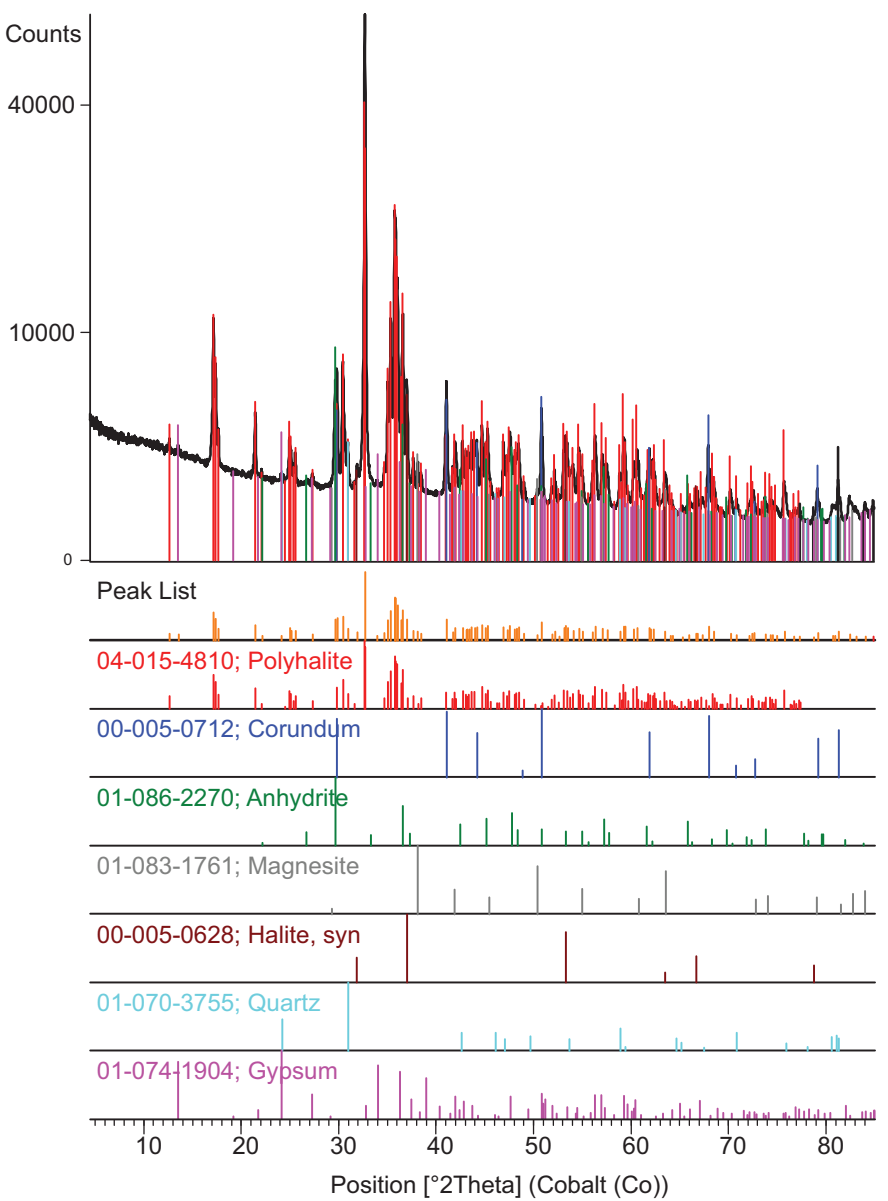

Fig. 4. Example powder XRD trace (black) with extracted peak information and identified mineral phases (including the standard corundum) displayed as stick patterns below. The complexity of the pattern is emphasized by superimposing the stick patterns on the sample trace.

in the Fordon (Evaporite) Formation; sylvite, halite, anhydrite, boracite, hilgardite, danburite, and dolomite in the Gough seam; and sylvite, halite, anhydrite, kainite, and kieserite in the Pasture Beck seam (Table 2). However, a much more extensive list of trace mineral components was also identified (Table 2). For many of these trace phases, identifications are tentative, as due to widespread peak overlap and their low concentrations, diagnostic peaks were severely limited. Also due to their similar atomic structure and common chemical composition, many of the phases identified present very similar XRD patterns. Differentiation is therefore very difficult or impossible in many cases. For example, it was difficult to distinguish between the borate minerals howlite and szaibelyite as both minerals exhibit their most intense peak at $6.24 \AA$ and all their other significant reflections were obscured by other mineral phases. In other cases borate-group minerals (e.g., nobleite, kernite, hexaborite, etc.) were only tentatively identified as these were purely based on a single XRD peak. No attempt was made to characterize the nature of phyllosilicate/clay minerals in the potash-bearing samples other than using the broad descriptor "undifferentiated." Full characterization would require their concentration, the preparation of oriented mounts, and the application of a diagnostic XRD testing program.

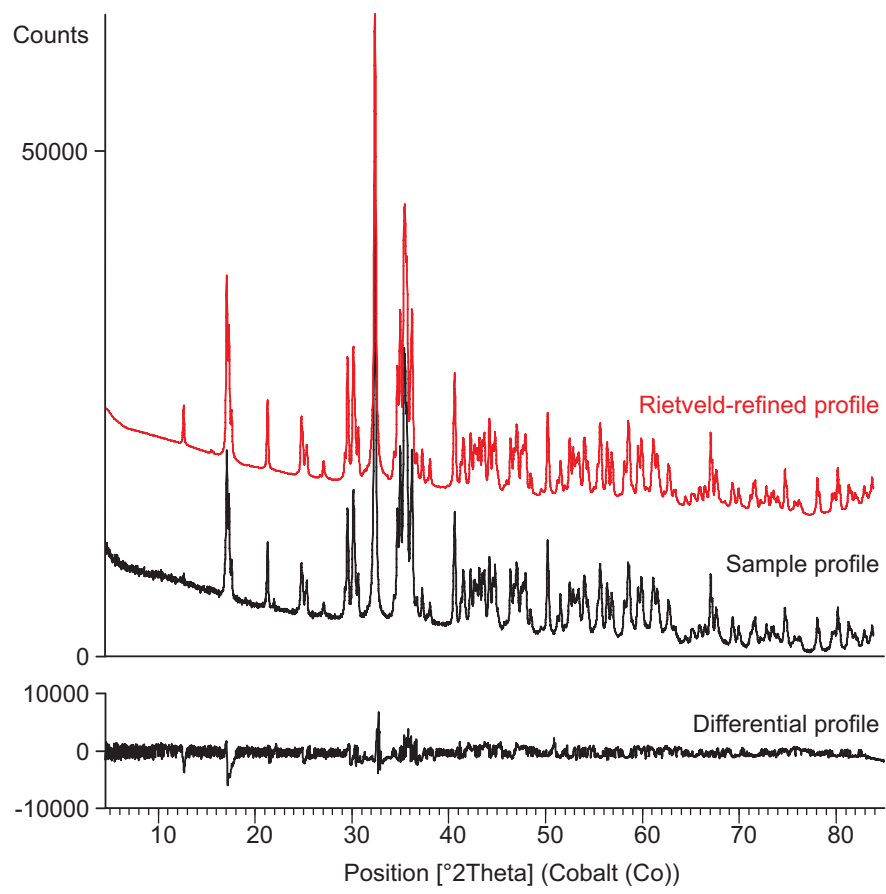

Fig. 5. Example powder XRD trace (experimental, black, upper) together with Rietveld profile (calculated, red) and differential (black, lower) to illustrate the excellent agreement produced by the refinement methodology. Note the difference in intensity scale for upper and lower figures.

Gypsum was identified as a trace component of some of the samples. Diagenetically, gypsum should not be present in the in situ deposit, as samples have been retrieved from depths of $\sim 1,500 \mathrm{~m}$ (Stewart, 1963). Despite the exclusion of all water from drilling, slabbing, and logging procedures, it is most likely that these traces of gypsum represent surface rehydration of anhydrite following atmospheric contact. In the historic borehole samples (Stoupe Beck, drilled in 1997/1998; Eskdale 11, drilled in 1958; Eskdale 13, drilled in 2001), gypsum transformation (after anhydrite) has proceeded to a greater degree during subsequent storage. It is noticeable that the gypsum has developed where major amounts of anhydrite were identified and was likely facilitated by the high surface area provided by the cuttings nature of these samples. During the latter stages of the project, initial XRD analysis of anhydrite-rich core samples surprisingly indicated high concentrations of gypsum, reaching $20 \%$ in some cases. Comparative XRD analysis confirmed that gypsum was not present at these levels in the equivalent ball-milled samples and that it had therefore been produced during subsequent preparation for XRD analysis. However, no such levels of gypsum had been produced during the preparation of previous batches of samples, despite an identical procedure being employed. It would therefore appear that gypsum developed in the anhydrite-rich samples by absorption of atmospheric water during the postmicronizing, fume cupboard evaporation of acetone. Unlike all previous samples treated in this way, these samples were prepared during particularly hot, humid weather conditions that could provide the moisture to react with the high surface area of the fine-grained $(\sim<5 \mu \mathrm{m})$, micronized anhydrite. Preparation of the affected samples was repeated to prevent gypsum development. 
Table 2. Minerals Identified in the Gough Seam, Pasture Beck Seam, and Fordon (Evaporite) Formation

\begin{tabular}{|c|c|c|}
\hline & Major mineral components & Trace mineral components \\
\hline Pasture Beck seam & $\begin{array}{l}\text { Sylvite, } \mathrm{KCl} \\
\text { Halite, } \mathrm{NaCl}\end{array}$ & $\begin{array}{l}\text { Quartz, } \mathrm{SiO}_{2} \\
\text { Talc, } \mathrm{Mg}_{3} \mathrm{Si}_{4} \mathrm{O}_{10}(\mathrm{OH})_{2}\end{array}$ \\
\hline SM1 & $\begin{array}{l}\text { Anhydrite, } \mathrm{CaSO}_{4} \\
\text { Kainite, } \mathrm{KMg}\left(\mathrm{SO}_{4}\right) \mathrm{Cl} \cdot\left(\mathrm{H}_{2} \mathrm{O}\right)_{2.75}\end{array}$ & $\begin{array}{l}\text { Mica, undifferentiated } \\
\text { Hexahydrite, } \mathrm{MgSO}_{4} \cdot 6 \mathrm{H}_{2} \mathrm{O}\end{array}$ \\
\hline Total 87 analyses & Kieserite, $\mathrm{MgSO}_{4} \cdot \mathrm{H}_{2} \mathrm{O}$ & \\
\hline
\end{tabular}

Once mineral phases had been identified, interpretation of the XRD patterns was extended to producing quantitative data using the Rietveld refinement approach. Prior to sample analysis, a series of mineral standards from the British Geological Survey collections (polyhalite, sylvite, and halite) were analyzed to establish their purity. Once their purity was established, these standards were used to produce a series of synthetic mixtures in order to validate the methodology and determine error values.

For Rietveld refinement, first, the most suitable structural data files were identified and downloaded from the Inorganic Crystal Structure Database for each of the component mineral phases to produce a composite standard profile. A series of sequential, least-square refinements were then performed on the composite profile to match the sample profile. Typically the refinements included background, scale factors, zero shift, unit cell (a, b, c, alpha, beta, gamma), preferred orientation and profile variables $(\mathrm{u}, \mathrm{v}$ and $\mathrm{w})$ to minimize the differential profile. With experience, excellent profile matches (e.g., borehole SM2; Fig. 5) were obtained with $\mathrm{R}^{2}$ values typically less than 5.6.
Mineralogical assemblages determined from QXRD analysis were then presented as downhole distribution plots (e.g., borehole SM2, Fig. 6) and compared with gamma-ray profiles and geochemical analyses.

\section{Potassium-bearing mineralogy}

QXRD together with geochemical analyses confirmed the sylvite-bearing nature of the secondary exploration targets in the shallower Sneaton Potash and Boulby Potash members together with the previously unreported Gough seam, intercepted and analyzed in boreholes SM1, SM4, SM7, SM7A, SM11, and SM11A; and the Pasture Beck seam intercepted in SM1.

QXRD also revealed the polyhalite-rich composition (in places exceeding $99 \%$ polyhalite) of the deeper Fordon (Evaporite) Formation. Two polyhalite-rich seams were evident, referred to as the Shelf and Basin seams (Figs. 6, 12). The Shelf seam (or Upper Polyhalite) was intercepted by boreholes SM2, SM3, SM3A, SM4, SM6, SM7, SM7A, SM9, SM9A, SM9B, SM11, SM11A, SM11B, Eskdale 11 and 13 


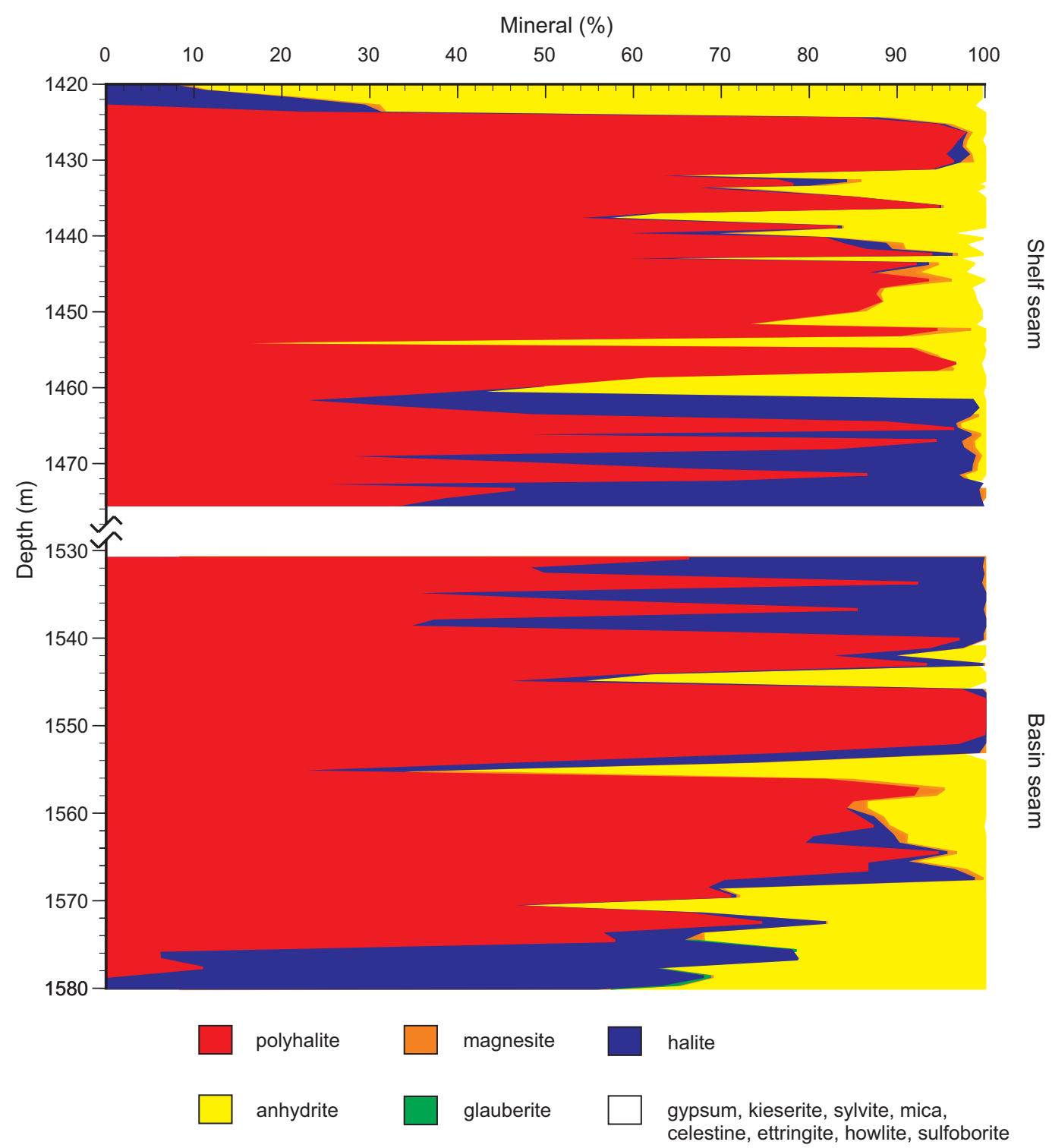

Fig. 6. QXRD-derived downhole distribution of mineral species for borehole SM2, clearly demonstrating the presence of two polyhalite-rich intervals; the Shelf and Basin seams.

between 1,273 and 1,384 m below Ordnance Datum. The deeper Basin seam (or Lower Polyhalite) was intercepted by boreholes SM1, SM2, and Stoupe Beck between 1,384 and $1,530 \mathrm{~m}$ below Ordnance Datum.

As well as polyhalite, minor quantities $(<7 \%)$ of kainite $\left(\mathrm{KMg}\left(\mathrm{SO}_{4}\right) \mathrm{Cl} \cdot\left(\mathrm{H}_{2} \mathrm{O}\right)_{2.75}\right)$ were consistently identified through the Pasture Beck seam in borehole SM1 and as a trace component of the polyhalite-rich interval in SM11B. Minor quantities of langbeinite $\left(\mathrm{K}_{2} \mathrm{Mg}_{2}\left(\mathrm{SO}_{4}\right)_{3}\right)$ and picromerite $\left(\mathrm{K}_{2} \mathrm{Mg}\left(\mathrm{SO}_{4}\right)_{2} \cdot 6\left(\mathrm{H}_{2} \mathrm{O}\right)\right)$ were identified in the upper parts of the Gough seam in borehole SM1 and in SM11B, while traces of sylvite were detected in most of the boreholes including SM1, SM2, SM9, SM9A, SM9B, SM11, SM11A, SM11B, and Stoupe Beck 1 . Traces of syngenite $\left(\mathrm{K}_{2} \mathrm{Ca}\left(\mathrm{SO}_{4}\right)_{2} \cdot 2\left(\mathrm{H}_{2} \mathrm{O}\right)\right)$ were also detected in the SM11A and Eskdale 11 borehole samples. Undifferentiated "mica," almost certainly including K-rich mica species, was detected in both the Gough seam
(SM1, SM4, SM7, and SM7A) and Fordon (Evaporite) Formation seams (all boreholes except SM1). In most cases, these formed only trace amounts but particularly micaceous zones (up to 10\% "mica") were detected in the upper parts of the Gough seam in boreholes SM4 and SM7 and to a lesser extent in the lower part of the Fordon (Evaporite) Formation in SM7. Confirmation of the K-bearing nature of the micas would require further analysis.

More significantly, kalistrontite $\left(\mathrm{K}_{2} \mathrm{Sr}\left(\mathrm{SO}_{4}\right)_{2}\right)$ was identified as forming more than $50 \%$ of the mineral assemblage in parts of the sampled interval of borehole SM6 and a smaller proportion $(<10 \%)$ in boreholes SM9, SM9A, and SM9B.

\section{Boron-bearing mineralogy}

QXRD analysis together with petrographic analysis of polished thin sections identified a range of boron-bearing minerals in the sampled sequence. 
Boracite $\left(\mathrm{Mg}_{3} \mathrm{~B}_{7} \mathrm{O}_{13} \mathrm{Cl}\right)$ was ubiquitously identified in the Gough seam in boreholes SM4, SM7, SM7A, SM11, and SM11A, representing up to $\sim 19 \%$ of the mineral assemblage. More locally in the Gough seam, hilgardite $\left(\mathrm{Ca}_{2} \mathrm{~B}_{5} \mathrm{ClO}_{9} \cdot\left(\mathrm{H}_{2} \mathrm{O}\right)\right)$ was developed as a trace phase in samples from borehole SM4 but forms more extensively and more than $50 \%$ assemblage in borehole SM7. The shallowest samples from the Gough seam in borehole SM4 $(\sim 1,233$ $\mathrm{m}$ below Ordnance Datum) additionally contain danburite $\left(\mathrm{CaB}_{2}\left(\mathrm{SiO}_{4}\right)_{2}\right.$, to $\left.\sim 20 \%\right)$ and tourmaline (undifferentiated, to $\sim 5 \%)$.

In the deeper Fordon (Evaporite) Formation, a more extensive range of boron-bearing minerals was identified, but these are generally present as trace phases. Szaibelyite $\left(\mathrm{MgBO}_{2}(\mathrm{OH})\right)$ is the most common boron-bearing mineral in the formation, generally occurring as a sporadic trace component throughout the interval in boreholes SM3A, SM4, SM7, SM7A, SM9, SM9A, SM9B, SM11, SM11A, SM11B, and Eskdale 11 but reaches a greater concentration of 5\% (SM9B, $1,555 \mathrm{~m})$. Traces of sulfoborite $\left(\mathrm{Mg}_{3} \mathrm{~B}_{2}\left(\mathrm{SO}_{4}\right)(\mathrm{OH})_{9} \mathrm{~F}\right)$ were detected in boreholes SM2 (1,433-1,445 m), SM7, SM7A, and SM11A while traces of howlite $\left(\mathrm{Ca}_{2} \mathrm{~B}_{5} \mathrm{SiO}_{9}(\mathrm{OH})_{5}\right)$ were noted in boreholes SM2 and SM3. Fluoborite $\left(\mathrm{Mg}_{3} \mathrm{~F}_{3}\left(\mathrm{BO}_{3}\right)\right)$ typically forms a rare trace component of the polyhalite in boreholes SM11A and SM11B but forms $~ 5 \%$ of one sample in SM11A. Uniquely for the formation, a trace of boracite was detected in borehole SM11A.

\section{Discussion}

\section{Quantitative determination of potash minerals}

Early in the investigation, comparison of the QXRD results with ICP-AES data obtained following traditional, slow fusion with lithium metaborate for the polyhalite-bearing intervals indicated good agreement at both high and low polyhalite contents. However, where samples contained a significant proportion of halite, QXRD and ICP-AES K content-derived polyhalite concentrations showed an alarming disparity resulting in a "banana-shaped" correlation plot (Table 3, Fig. 7A). Confusingly, ICP-AES-derived mineral concentrations from other elements $(\mathrm{Ca}, \mathrm{Mg}$, and $\mathrm{Na}$ ) produced straight-line correlations with QXRD polyhalite (e.g., Fig. 7C) and QXRD halite (Fig. 7D), respectively.

As the nonstandard technique, the QXRD analytical data were immediately thought to be erroneous. Therefore, in order to provide further validation of the QXRD results, duplicate samples were also analyzed using thermogravimetric

Table 3. Comparison of $\% \mathrm{~K}_{2} \mathrm{O}$ Concentration Derived from QXRD, ICP-AES (slow fusion), and ICP-AES (fast fusion)

\begin{tabular}{|c|c|c|c|c|c|c|c|c|c|}
\hline \multirow[b]{2}{*}{ Borehole } & \multirow[b]{2}{*}{ Depth (m) } & \multicolumn{3}{|c|}{$\% \mathrm{~K}_{2} \mathrm{O}$} & \multirow[b]{2}{*}{ Borehole } & \multirow[b]{2}{*}{ Depth (m) } & \multicolumn{3}{|c|}{$\% \mathrm{~K}_{2} \mathrm{O}$} \\
\hline & & QXRD & $\begin{array}{c}\text { ICP-AES } \\
\text { (slow) }\end{array}$ & $\begin{array}{c}\text { ICP-AES } \\
\text { (fast) }\end{array}$ & & & QXRD & $\begin{array}{c}\text { ICP-AES } \\
\text { (slow) }\end{array}$ & $\begin{array}{c}\text { ICP-AES } \\
\text { (fast) }\end{array}$ \\
\hline \multirow[t]{36}{*}{ SM1 } & $1616.91-1617.33$ & 8.31 & 5.36 & 7.67 & \multirow[t]{36}{*}{ SM1 } & $1640.03-1640.96$ & 15.62 & 15.59 & 15.82 \\
\hline & $1617.33-1617.75$ & 6.47 & 3.59 & 5.64 & & $1640.96-1641.51$ & 7.67 & 7.58 & 7.36 \\
\hline & $1617.75-1618.40$ & 12.32 & 9.27 & 11.21 & & $1641.51-1641.95$ & 14.92 & 14.27 & 14.16 \\
\hline & $1618.40-1618.89$ & 15.17 & 14.87 & 14.93 & & 1641.95-1642.88 & 15.60 & 15.89 & 15.92 \\
\hline & 1618.89-1619.39 & 15.54 & 15.21 & 15.31 & & $1642.88-1643.51$ & 15.60 & 15.66 & 15.59 \\
\hline & 1619.39-1619.89 & 15.54 & 16.03 & 15.18 & & $1643.51-1644.25$ & 15.60 & 15.48 & 15.33 \\
\hline & 1619.89-1620.39 & 15.57 & 16.20 & 15.68 & & $1644.25-1644.66$ & 15.60 & 15.34 & 15.05 \\
\hline & $1620.39-1621.00$ & 14.78 & 15.02 & 14.23 & & $1644.66-1644.93$ & 15.60 & 15.06 & 15.61 \\
\hline & $1621.00-1621.50$ & 15.23 & 15.26 & 14.80 & & $1644.93-1645.50$ & 15.60 & 14.39 & 15.22 \\
\hline & $1621.50-1622.00$ & 14.15 & 13.35 & 13.03 & & $1645.50-1645.97$ & 15.60 & 15.29 & 15.43 \\
\hline & $1622.00-1622.50$ & 14.48 & 13.47 & 13.63 & & $1645.97-1646.47$ & 15.60 & 15.91 & 15.57 \\
\hline & $1622.50-1622.98$ & 14.82 & 14.83 & 14.43 & & $1646.47-1646.97$ & 15.60 & 15.33 & 15.33 \\
\hline & $1622.98-1623.48$ & 15.57 & 16.52 & 15.26 & & $1646.97-1647.37$ & 15.60 & 15.54 & 15.87 \\
\hline & $1623.48-1623.98$ & 15.46 & 15.90 & 15.40 & & $1647.37-1647.64$ & 15.60 & 15.42 & 15.15 \\
\hline & $1623.98-1624.48$ & 14.96 & 14.70 & 14.29 & & $1647.64-1647.95$ & 15.62 & 15.90 & 15.45 \\
\hline & $1624.48-1624.91$ & 14.71 & 14.01 & 14.58 & & $1647.95-1648.50$ & 15.60 & 15.05 & 15.76 \\
\hline & $1624.91-1625.41$ & 14.53 & 13.55 & 13.99 & & $1648.50-1648.92$ & 15.07 & 13.82 & 14.90 \\
\hline & $1625.41-1625.91$ & 14.35 & 13.43 & 13.74 & & $1648.92-1649.16$ & 9.89 & 7.04 & 9.10 \\
\hline & $1625.91-1626.41$ & 13.82 & 12.82 & 13.46 & & $1649.16-1649.50$ & 15.01 & 13.88 & 14.43 \\
\hline & $1626.41-1626.85$ & 12.84 & 10.35 & 11.69 & & $1649.50-1650.50$ & 2.70 & 1.01 & 1.88 \\
\hline & $1626.85-1627.16$ & 12.26 & 9.52 & 10.94 & & $1656.90-1651.38$ & 3.73 & 1.77 & 2.88 \\
\hline & $1627.16-1627.50$ & 10.65 & 7.42 & 9.10 & & $1657.38-1657.81$ & 4.47 & 1.75 & 3.46 \\
\hline & $1627.50-1628.00$ & 7.20 & 4.20 & 6.14 & & $1657.81-1658.95$ & 15.26 & 14.75 & 15.36 \\
\hline & $1632.42-1633.34$ & 1.86 & 0.82 & 1.29 & & $1658.95-1659.91$ & 15.53 & 15.91 & 15.94 \\
\hline & $1633.34-1633.88$ & 3.19 & 1.36 & 2.50 & & $1659.91-1660.79$ & 15.28 & 14.83 & 14.80 \\
\hline & $1633.88-1634.92$ & 15.46 & 15.31 & 15.49 & & 1660.79-1661.61 & 14.09 & 12.93 & 13.85 \\
\hline & $1634.92-1635.42$ & 15.59 & 15.23 & 15.61 & & $1661.61-1662.05$ & 13.18 & 12.06 & 12.59 \\
\hline & $1635.42-1635.92$ & 15.60 & 15.75 & 15.38 & & $1662.05-1662.58$ & 14.17 & 12.87 & 13.67 \\
\hline & $1635.92-1636.42$ & 15.60 & 15.79 & 15.66 & & $1662.58-1663.04$ & 10.09 & 7.28 & 9.26 \\
\hline & $1636.42-1636.82$ & 15.60 & 15.66 & 15.32 & & 1663.04-1663.45 & 9.23 & 5.94 & 8.36 \\
\hline & $1636.82-1637.32$ & 14.96 & 14.06 & 13.97 & & $1663.45-1663.93$ & 15.42 & 14.78 & 15.40 \\
\hline & 1637.32-1637.82 & 15.60 & 15.33 & 15.15 & & 1663.93-1664.39 & 13.56 & 12.12 & 13.28 \\
\hline & $1637.82-1638.32$ & 15.60 & 15.77 & 15.66 & & 1664.39-1664.71 & 13.28 & 11.30 & 13.06 \\
\hline & 1638.32-1638.71 & 15.60 & 16.19 & 15.56 & & $1664.71-1664.97$ & 11.04 & 8.06 & 10.22 \\
\hline & $1638.71-1639.08$ & 15.60 & 15.74 & 15.72 & & $1664.97-1665.97$ & 7.95 & 4.75 & 6.79 \\
\hline & $1639.08-1640.03$ & 15.60 & 14.51 & 15.46 & & & & & \\
\hline
\end{tabular}


(A)

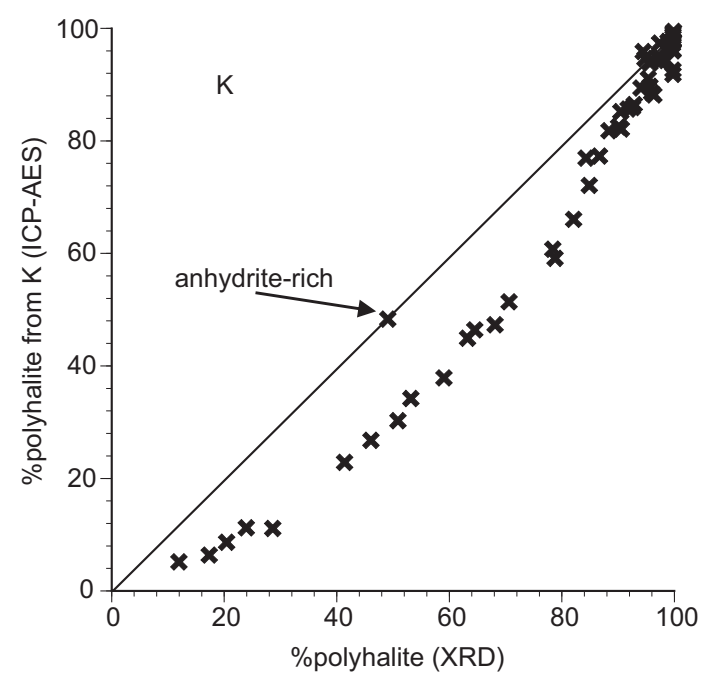

(C)

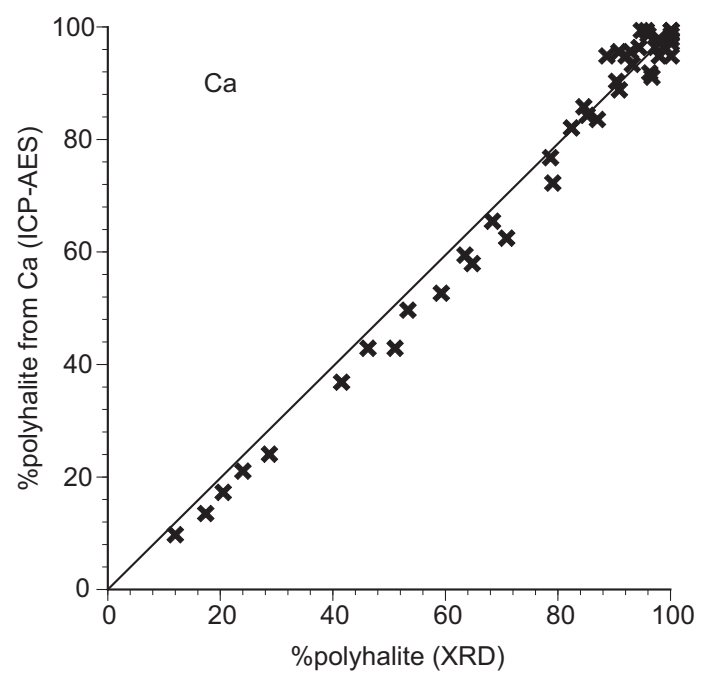

(B)

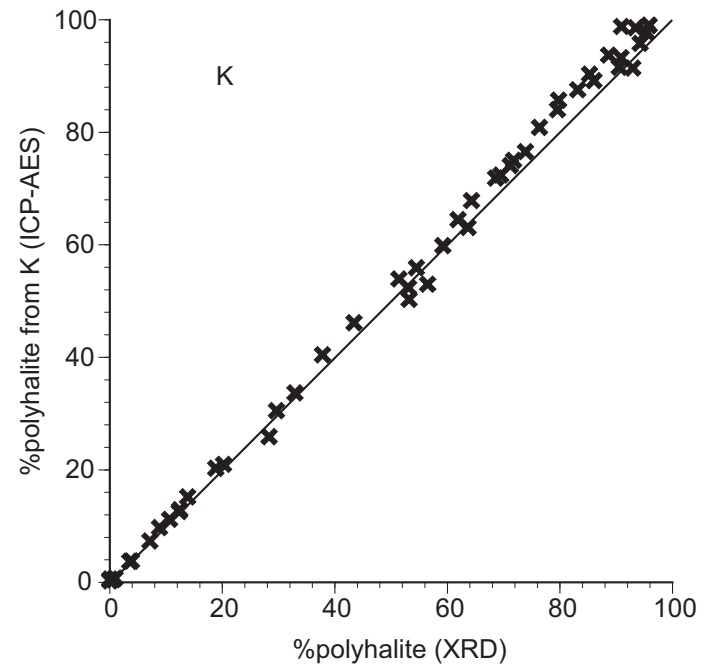

(D)

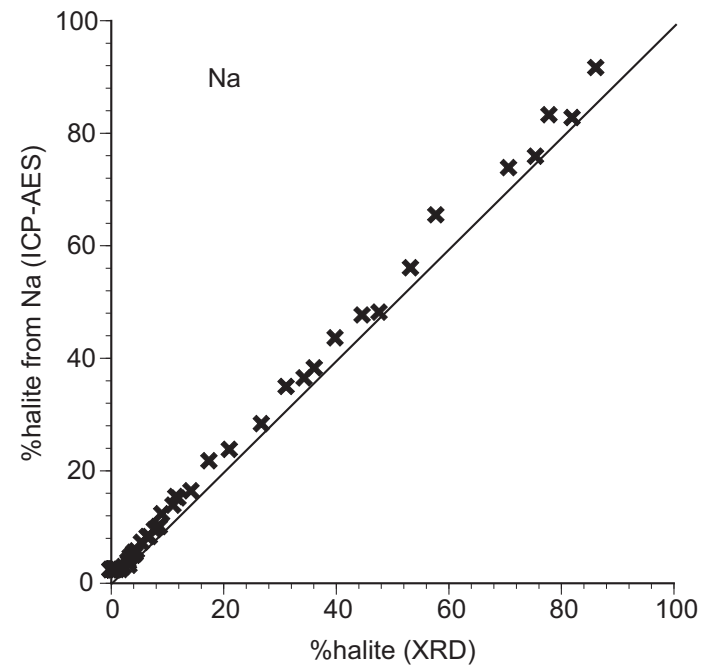

Fig. 7. Cross plots for QXRD- and ICP-AES-derived data, SM1 borehole. A. \% polyhalite (XRD) vs. K-derived \% polyhalite (ICP-AES), using traditional, slow lithium metaborate fusion prior to ICP-AES. B. \% polyhalite (XRD) vs. K-derived \% polyhalite (ICP-AES), using new, rapid lithium metaborate fusion prior to ICP-AES. C. \% polyhalite (XRD) vs. Ca-derived \% polyhalite (ICP-AES), using traditional, slow lithium metaborate fusion prior to ICP-AES. D. \% halite (XRD) vs. Na-derived $\%$ halite (ICP-AES), using traditional, slow lithium metaborate fusion prior to ICP-AES.

analysis-simultaneous differential thermal analysis-mass-spectrometry (TGA-SDTA-MS) and XRFS laboratory instruments.

Thermogravimetric validation: Thermogravimetric analysis (TGA) of a pure sample of polyhalite in flowing nitrogen produces a single weight loss between $\sim 215^{\circ}$ and $410^{\circ} \mathrm{C}$ with an inflexion point at $342^{\circ} \mathrm{C}$. Further investigation of polyhalite thermal behavior was precluded by the melting and frothing of samples above $420^{\circ} \mathrm{C}$. The $\sim 342^{\circ} \mathrm{C}$ weight loss represents $5.98 \%$ sample mass and the DTA profile indicates that the reaction is endothermic. Mass spectrometry reveals that the weight loss is produced by the evolution of two moles of water (Fig. 8). Fischer et al. (1996) concurred that polyhalite decomposes in a single step and, using XRD techniques, determined that the reaction products were anhydrite and two solid solutions of composition $\mathrm{K}_{2} \mathrm{SO}_{4} \cdot 1.76 \mathrm{MgSO}_{4} \cdot 0.24 \mathrm{CaSO}_{4}$ and $\mathrm{K}_{2} \mathrm{SO}_{4} \cdot 0.64 \mathrm{MgSO}_{4} \cdot 1.36 \mathrm{CaSO}_{4}$.

For many samples, a lack of conflicting weight losses from other component minerals means that accurate measurement of the same $\sim 215^{\circ}$ to $410^{\circ} \mathrm{C}$ weight loss (often with the aid of the derivative (DTG) curve) and comparison with the standard 5.98\% weight loss (Fischer et al., 1996; Bish and Scanlon, 2006) can provide a reliable assay of polyhalite grade. However where overlapping weight losses occur, TGA traces are more difficult to interpret and assays are less reliable. For example, the low-temperature, two-step dehydration of gypsum (total $20.93 \%$ weight loss between $60^{\circ}$ and $240^{\circ} \mathrm{C}$, e.g., Lager et al., 1984) obscures the onset and delimiting of polyhalite dehydration. Similarly the higher temperature decomposition of magnesite $\left(52.2 \%\right.$ weight loss between $\sim 400^{\circ}$ and $800^{\circ} \mathrm{C}$, Mackenzie, 1972) creates difficulties in establishing an end-point for the polyhalite dehydration. The extensive range of water- and carbonate-bearing minerals identified in the deposit (Table 2) means that many other species (e.g., kieserite, $\sim 13 \%$ weight loss between $\sim 300^{\circ}$ and $400^{\circ} \mathrm{C}$, Todor, 1976 , and szaibelyite, $3.39 \%$ weight loss between $\sim 150^{\circ}$ and $600^{\circ} \mathrm{C}$, Marincea, 2001) are likely to contribute weight losses 


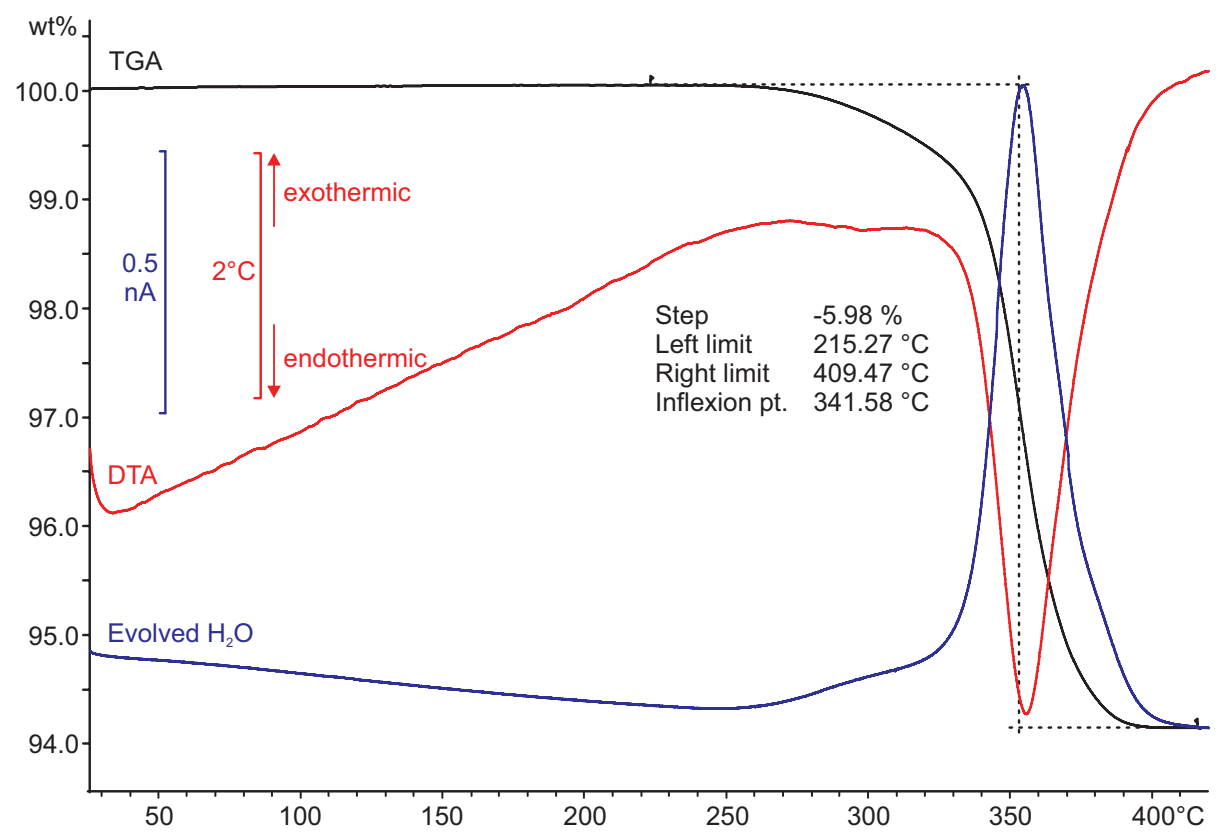

Fig. 8. Example thermogravimetric analysis (TGA) and accompanying differential thermal analysis (DTA) traces together with evolved $\mathrm{H}_{2} \mathrm{O}$ mass spectrometer output for a sample of pure polyhalite.

in the $200^{\circ}$ to $400^{\circ} \mathrm{C}$ temperature interval. However, these gangue species typically form only minor trace components of the deposit and their inputs are likely to be small, particularly in the high-grade polyhalite sections of most interest.

Cross-plotting the example polyhalite quantification results of QXRD and TGA (Table 4, Fig. 9A) for samples from borehole SM11 reveals a typical, excellent correlation $\left(\mathrm{R}^{2}=0.9987\right)$. XRD also explains that the four samples falling farthest from the 1:1 correlation line all contain small quantities of kieserite $\left(\mathrm{MgSO}_{4} \cdot \mathrm{H}_{2} \mathrm{O}\right)$. Kieserite releases its bound water between $230^{\circ}$ and $400^{\circ} \mathrm{C}$, with a corresponding weight loss of $13.02 \%$ (Emons et al., 1990). Thermogravimetric analysis assays therefore underestimate polyhalite grade for kieserite-bearing samples.

Geochemical validation: Similarly the QXRD polyhalite concentrations also show an excellent correlation with laboratory XRFS analyses (the benchmark method for determining total elemental concentrations in solid samples and carried out by a UKAS accredited laboratory, PANalytical Ltd., UKAS 7488 ) on a small subset of six samples with $\mathrm{K}$ concentrations across the full range encountered in samples analyzed (Table 4, Fig. 9B, $\left.\mathrm{R}^{2}=0.9947\right)$. Similarly strong, positive correlations were also obtained for other polyhalite-bearing elements$\mathrm{Mg}, \mathrm{Ca}$, and $\mathrm{SO}_{3}$ (Fig. 9C-E).

The close agreement of polyhalite-grade determinations from three disparate laboratory techniques (QXRD, TGA, and XRFS, Table 4) clearly demonstrates the accuracy of the QXRD analyses. Attention therefore switched to the validity of the traditional ICP-AES geochemical data.

Good correlations between QXRD and ICP-AES fusion data for several major elements (Ca, Na; Fig. 7C, D) suggested that there was no universal recovery or performance failing and the issue was restricted to $\mathrm{K}$ data. Closer inspection of the $\mathrm{K}$ recovery curve (Fig. 7A) further showed that for high-purity polyhalite samples the K recovery agreed well with QXRD data. However, as the proportion of polyhalite in the sample (determined by
QXRD) decreased, the ICP-AES results underrepresented the amount of $\mathrm{K}$ present, with the size of the relative discrepancy increasing monotonically. There was one important exception to this trend, for a sample containing roughly $50 \%$ polyhalite and $50 \%$ anhydrite, for which the $\mathrm{K}$ recovery was again excellent. The other samples in the dataset were formed of mixtures of polyhalite with halite. This indicated that the apparent loss of $\mathrm{K}$ was determined by the mineralogy of the sample rather than the absolute concentration of $\mathrm{K}$ or polyhalite. Further tests with additional material subsequently demonstrated that the underrecovery of polyhalite was directly proportional to the halite content in the samples.

Analytical checks demonstrated that the performance of the ICP-AES instrument was correctly measuring the true concentrations of $\mathrm{K}$ in the digested fusion solutions. The problem was therefore narrowed to a $\mathrm{K}$ loss during fusion in the presence of halite, but not other phases. Analysis of a test subset of the same samples using lithium borate fusion preparation of a glass bead followed by XRFS determination did not show the same loss of K. Significantly, the standard fusion procedure used by the XRFS laboratory was different from that currently in use for ICP-AES, being much faster and exposing the sample to high temperature for a shorter time. The ICP-AES analysis was therefore repeated using a modified fusion and dissolution involving placing the weighed sample crucibles directly into a preheated furnace for $10 \mathrm{~min}$ and removing promptly, rather than ramping the temperature from cold and cooling over a much longer period. The results showed significantly improved recovery of $\mathrm{K}$, with good linear agreement with the QXRD data over the full range of sample compositions (Table 3, Fig. 7B). The modified faster fusion procedure was then used for all subsequent ICP-AES analysis of the insoluble phases.

It is believed that the underrecovery seen during the earlier procedure is due to volatilization losses during the more extended fusion. Volatilization losses of this kind during fusion 
Table 4. Comparison of $\% \mathrm{~K}_{2} \mathrm{O}$ Concentration Derived from QXRD, ICP-AES (rapid fusion), TGA, and XRFS Analyses

\begin{tabular}{|c|c|c|c|c|c|c|c|c|c|c|c|}
\hline \multirow[b]{2}{*}{ Borehole } & \multirow[b]{2}{*}{ Depth $(\mathrm{m})$} & \multicolumn{4}{|c|}{$\% \mathrm{~K}_{2} \mathrm{O}$} & \multirow[b]{2}{*}{ Borehole } & \multirow[b]{2}{*}{ Depth (m) } & \multicolumn{4}{|c|}{$\% \mathrm{~K}_{2} \mathrm{O}$} \\
\hline & & QXRD & ICP-AES & TGA & XRFS & & & QXRD & ICP-AES & TGA & XRFS \\
\hline \multirow[t]{6}{*}{ SM1 } & $1622.50-1622.98$ & 14.82 & 14.43 & 14.73 & 14.81 & \multirow[t]{35}{*}{ SM11 } & $1524.92-1526.10$ & 11.22 & 11.73 & 11.13 & na \\
\hline & $1626.85-1627.16$ & 12.26 & 10.94 & 11.60 & 11.77 & & $1526.10-1526.98$ & 10.04 & 10.62 & 9.98 & na \\
\hline & $1627.50-1628.00$ & 7.20 & 6.14 & 6.59 & 6.73 & & $1526.98-1528.07$ & 11.93 & 12.64 & 11.90 & na \\
\hline & $1632.42-1633.34$ & 1.86 & 1.29 & 1.22 & 1.39 & & $1528.07-1528.90$ & 15.20 & 16.31 & 15.05 & na \\
\hline & $1657.38-1657.81$ & 4.47 & 3.46 & 3.68 & 3.85 & & $1528.90-1529.80$ & 15.06 & 15.91 & 15.02 & na \\
\hline & 1662.58-1663.04 & 10.09 & 9.26 & 9.39 & 9.78 & & $1529.80-1530.78$ & 15.09 & 15.97 & 14.97 & na \\
\hline \multirow{29}{*}{ SM11 } & $1496.86-1497.80$ & nd & 0.09 & nd & na & & $1530.78-1532.10$ & 14.96 & 15.48 & 14.85 & na \\
\hline & $1497.80-1498.72$ & nd & 0.07 & nd & na & & $1532.10-1533.14$ & 14.60 & 15.41 & 14.40 & na \\
\hline & $1498.72-1499.51$ & nd & 0.05 & nd & na & & $1533.14-1534.26$ & 15.00 & 16.01 & 14.91 & na \\
\hline & 1499.51-1501.07 & nd & 0.08 & nd & na & & $1534.26-1535.46$ & 14.98 & 15.49 & 14.75 & na \\
\hline & 1501.07-1501.96 & nd & 0.05 & nd & na & & $1535.46-1536.10$ & 14.73 & 14.98 & 14.53 & na \\
\hline & $1501.96-1502.82$ & 0.55 & 0.58 & 0.47 & na & & $1536.10-1536.81$ & 15.06 & 15.66 & 14.85 & na \\
\hline & $1502.82-1503.30$ & 1.66 & 1.75 & 1.51 & na & & $1536.81-1537.80$ & 14.79 & 15.73 & 14.79 & na \\
\hline & $1503.30-1504.40$ & 11.12 & 11.58 & 11.01 & na & & $1537.80-1538.63$ & 14.92 & 15.29 & 14.99 & na \\
\hline & $1504.40-1505.43$ & 10.86 & 11.33 & 10.82 & na & & $1538.63-1539.68$ & 5.90 & 6.32 & 5.99 & na \\
\hline & $1505.43-1506.44$ & 11.54 & 11.97 & 11.43 & na & & 1539.68-1540.44 & 2.16 & 2.37 & 2.11 & na \\
\hline & $1506.44-1507.20$ & 14.15 & 14.32 & 14.16 & na & & $1540.44-1541.52$ & 1.94 & 2.01 & 2.34 & na \\
\hline & $1507.20-1508.28$ & 9.67 & 10.08 & 9.67 & na & & $1541.52-1542.22$ & 1.92 & 1.96 & 2.16 & na \\
\hline & $1508.28-1509.74$ & 8.03 & 8.43 & 7.97 & na & & $1542.22-1543.60$ & 4.62 & 4.76 & 5.13 & na \\
\hline & $1509.74-1510.63$ & 12.46 & 13.40 & 12.41 & na & & $1543.60-1544.72$ & 8.51 & 8.74 & 9.06 & na \\
\hline & $1510.63-1511.37$ & 5.14 & 5.26 & 5.04 & na & & $1544.72-1545.62$ & 13.85 & 14.65 & 13.91 & na \\
\hline & 1511.37-1512.71 & 6.78 & 7.21 & 6.74 & na & & $1545.62-1546.46$ & 15.14 & 16.22 & 15.03 & na \\
\hline & $1512.71-1513.77$ & 1.11 & 1.14 & 1.03 & na & & $1546.46-1547.20$ & 14.20 & 14.59 & 15.28 & na \\
\hline & $1513.77-1514.73$ & nd & 0.03 & nd & na & & $1547.20-1548.30$ & 14.53 & 14.30 & 14.50 & na \\
\hline & $1514.73-1515.72$ & 0.09 & 0.07 & 0.03 & na & & $1548.30-1549.18$ & 13.45 & 13.94 & 13.39 & na \\
\hline & $1515.72-1516.66$ & 0.14 & 0.13 & 0.08 & na & & $1549.18-1550.18$ & 15.14 & 16.16 & 14.90 & na \\
\hline & $1516.66-1517.24$ & 0.59 & 0.60 & 0.46 & na & & $1550.18-1551.30$ & 8.83 & 8.29 & 8.64 & na \\
\hline & $1517.24-1517.84$ & 10.72 & 11.24 & 10.77 & na & & $1551.30-1552.26$ & 8.29 & 8.19 & 8.10 & na \\
\hline & $1517.84-1518.40$ & 13.00 & 13.70 & 12.98 & na & & $1552.26-1553.80$ & 4.42 & 4.05 & 4.21 & na \\
\hline & $1518.40-1519.50$ & 14.21 & 15.45 & 14.18 & na & & $1553.80-1555.02$ & 9.95 & 9.87 & 9.84 & na \\
\hline & $1519.50-1520.57$ & 13.32 & 14.12 & 13.28 & na & & $1555.02-1556.14$ & 8.31 & 7.86 & 8.08 & na \\
\hline & $1520.57-1521.47$ & 15.23 & 16.35 & 15.11 & na & & $1556.14-1557.25$ & 3.16 & 3.27 & 3.15 & na \\
\hline & $1521.47-1522.67$ & 15.12 & 16.34 & 15.03 & na & & $1557.25-1558.32$ & 2.94 & 3.16 & 3.02 & na \\
\hline & $1522.67-1523.98$ & 14.65 & 15.68 & 14.42 & na & & $1580.46-1581.76$ & 1.37 & 1.51 & 1.33 & na \\
\hline & 1523.98-1524.92 & 12.43 & 13.14 & 12.32 & na & & $1581.76-1582.49$ & 9.25 & 9.35 & 9.14 & na \\
\hline
\end{tabular}

Notes: nd $=$ not detected, na $=$ not available

have been documented for elements which form more predictably volatile oxide compounds such as $\mathrm{CO}_{2}$ and $\mathrm{NO}_{2}$ (e.g., Hettipathirana et al., 2003), while losses of lithium borate flux material have also been observed at higher temperatures, above $1,050^{\circ} \mathrm{C}$ (Loubser et al., 2004). However, this type of mineral-specific loss of a secondary element appears to be relatively unreported.

Problems with geochemical analyses in potash studies have previously been reported. For example, Crowl et al. (2011) noted that ICP-AES data underreported $\mathrm{K}$, as well as probably $\mathrm{Ca}, \mathrm{Mg}$, and $\mathrm{Sr}$, and suggested that these lower than expected values were explained by either precipitate formation or incomplete digestion.

Geophysical and HH-XRFS validation: The QXRD results also show excellent correlations with borehole gamma-ray (Figs. 10, 11) and hand-held (HH)-XRFS data. The gamma log profiles very closely match the QXRD distribution of polyhalite in boreholes SM7 and SM11 (Fig. 10A, C). The correlation is particularly impressive when one considers that the QXRD data are from borehole core while the gamma-ray measurements are from the rockmass surrounding the borehole and, therefore, two different sample volumes are being compared. Additionally, precise correlation of the gamma-ray log and sample depth is also difficult to achieve. However, as shown for the borehole SM7 profile (Fig. 10A), the gamma-ray response can overestimate polyhalite content (producing $>100 \%$ results) where concentrations are very high. Similar gamma-ray overestimations were encountered in Saskatchewan, Canada, by Hardy et al. (2010). However, other studies have indicated that gamma equiv $\mathrm{K}_{2} \mathrm{O} \%$ values provide underestimates compared to concentrations from laboratory assays. SRK Consulting (2011) suggested that the variance in the relationship of equiv $\mathrm{K}_{2} \mathrm{O} \%$ to assay $\mathrm{K}_{2} \mathrm{O}$ from borehole to borehole needs further evaluation, but perhaps reflects variations in potash mineralogy of the Holbrook basin potash deposit. Gamma-ray and laboratory (no technique is specified) comparison plots presented by Kruger (2013) suggest that gamma-ray-derived mineral concentrations may dramatically underestimate sylvite (e.g., gamma, 28\%; laboratory, 60\%) and carnallite (e.g., gamma, 40\%; laboratory, $60 \%$ ) content. Kruger (2013) suggested that where laboratory assays exceed those predicted from log analysis, the discrepancy may be due to a sample collected from a thin layer with higher radioactivity than the salt layers above and below it. The gamma-ray logging tool is unable to isolate thin layers of high radioactivity and as a result, the recorded measurement at any point represents an average of a 0.5- to 1-m interval. Thus, 
(A)

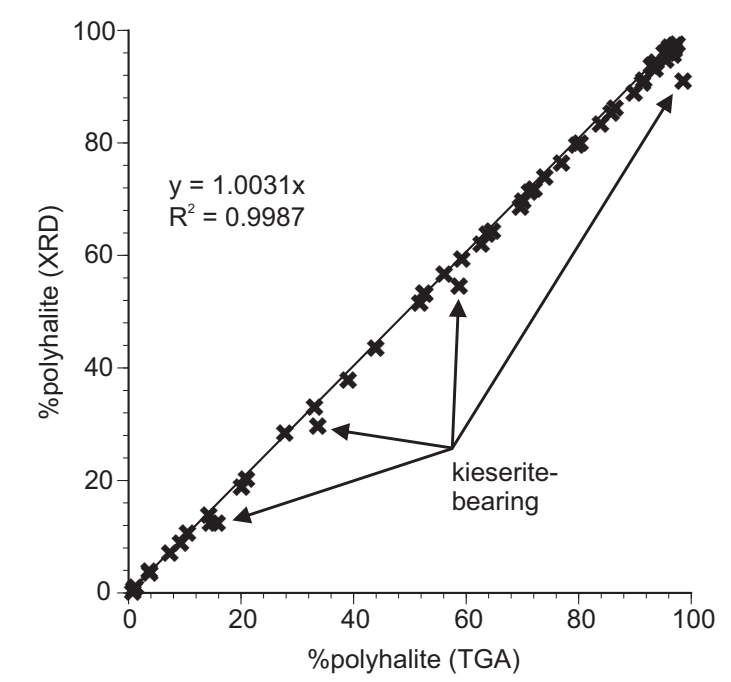

(C)

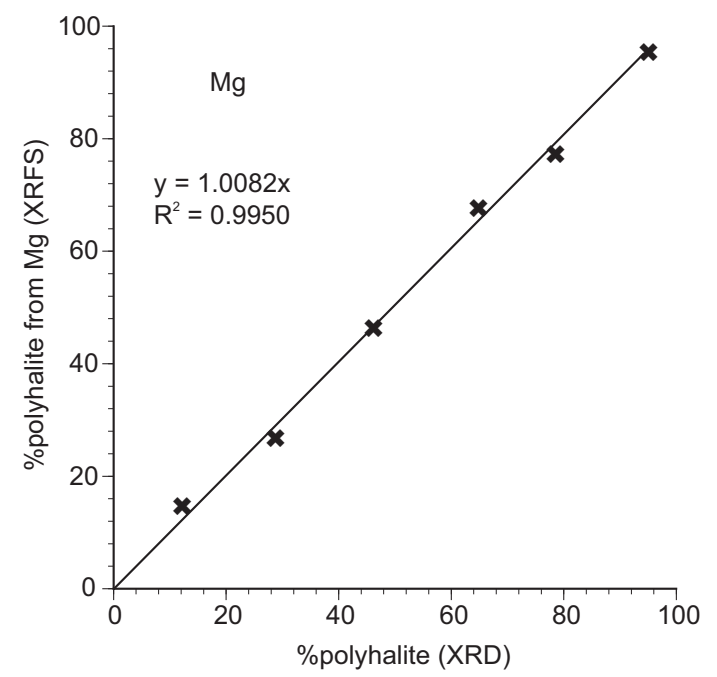

(B)

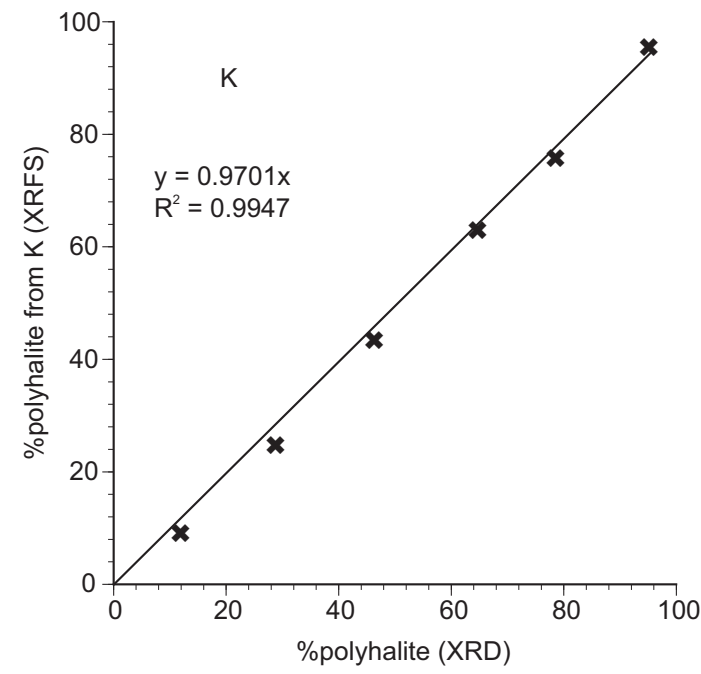

(D)

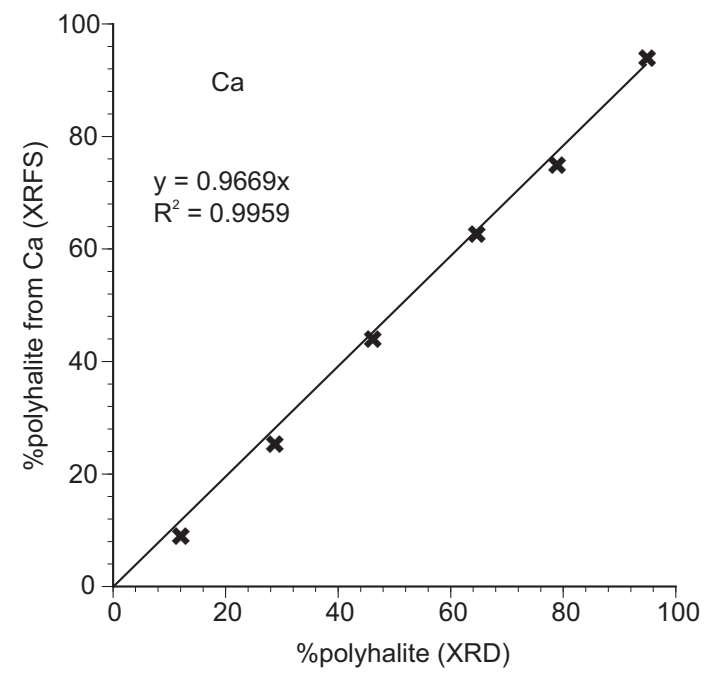

(E)

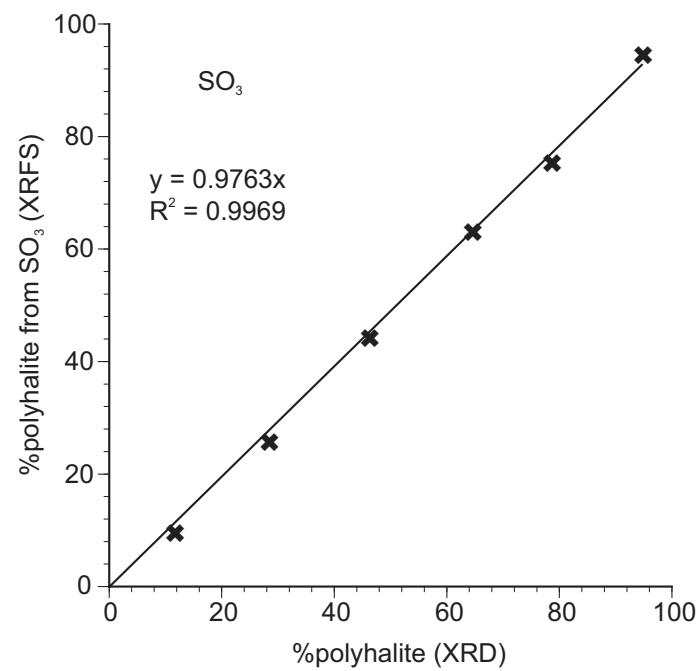

Fig. 9. Corroborative cross plots for QXRD-derived polyhalite assay with $\mathrm{R}^{2}$ correlation coefficients $>0.99$, SM11 borehole. A. TGA vs. QXRD. B. QXRD vs. K from XRFS. C. QXRD vs. Mg from XRFS. D. QXRD vs. Ca from XRFS. E. QXRD vs. $\mathrm{SO}_{3}$ from XRFS. XRD analysis suggests that the four samples falling furthest from the 1:1 TGA parity line, all contain small quantities of kieserite $\left(\mathrm{MgSO}_{4} \cdot \mathrm{H}_{2} \mathrm{O}\right)$. Kieserite releases bound water in a similar temperature range to the polyhalite dehydration and is responsible for TGA underestimates of polyhalite grade. 

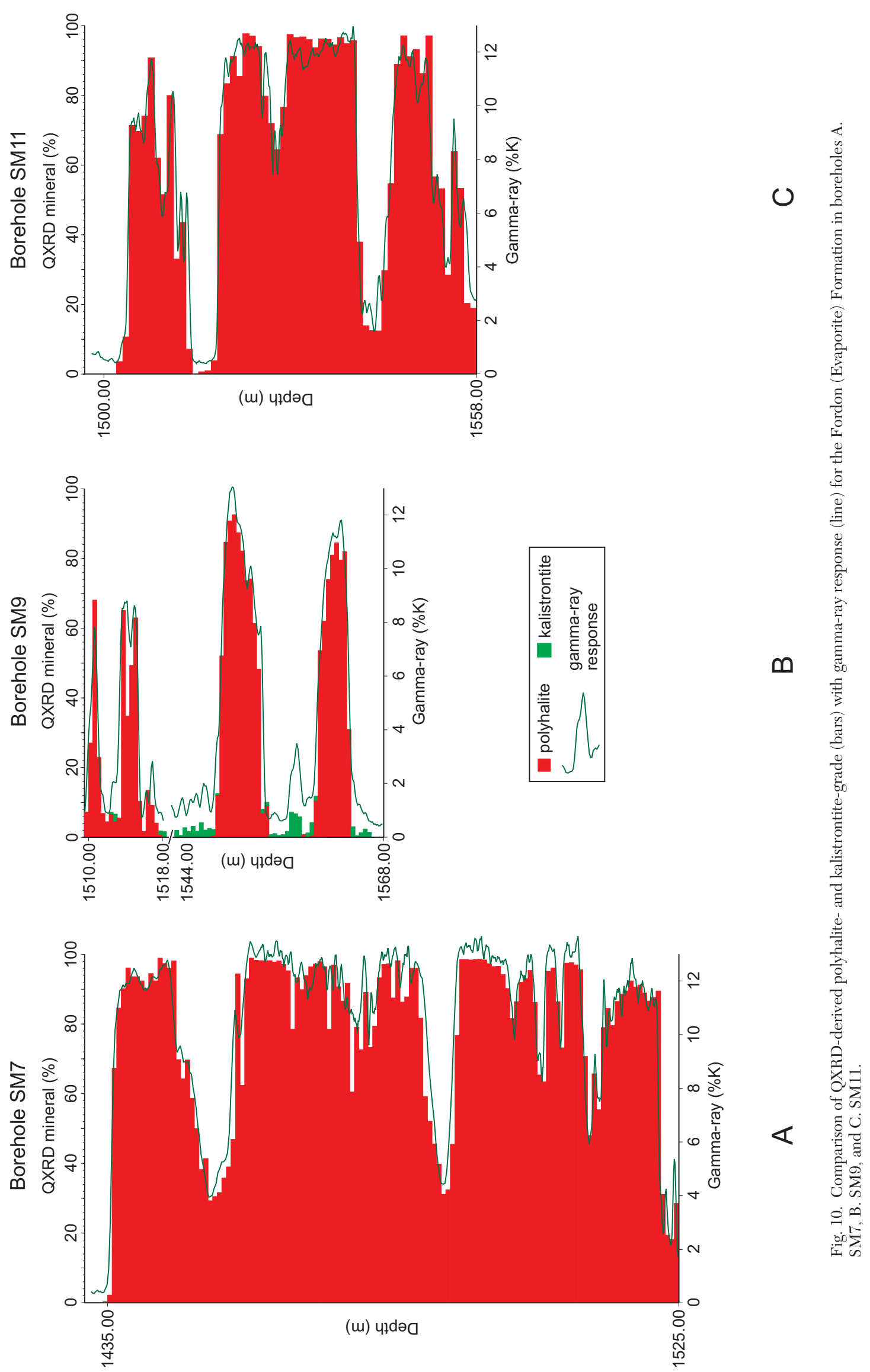


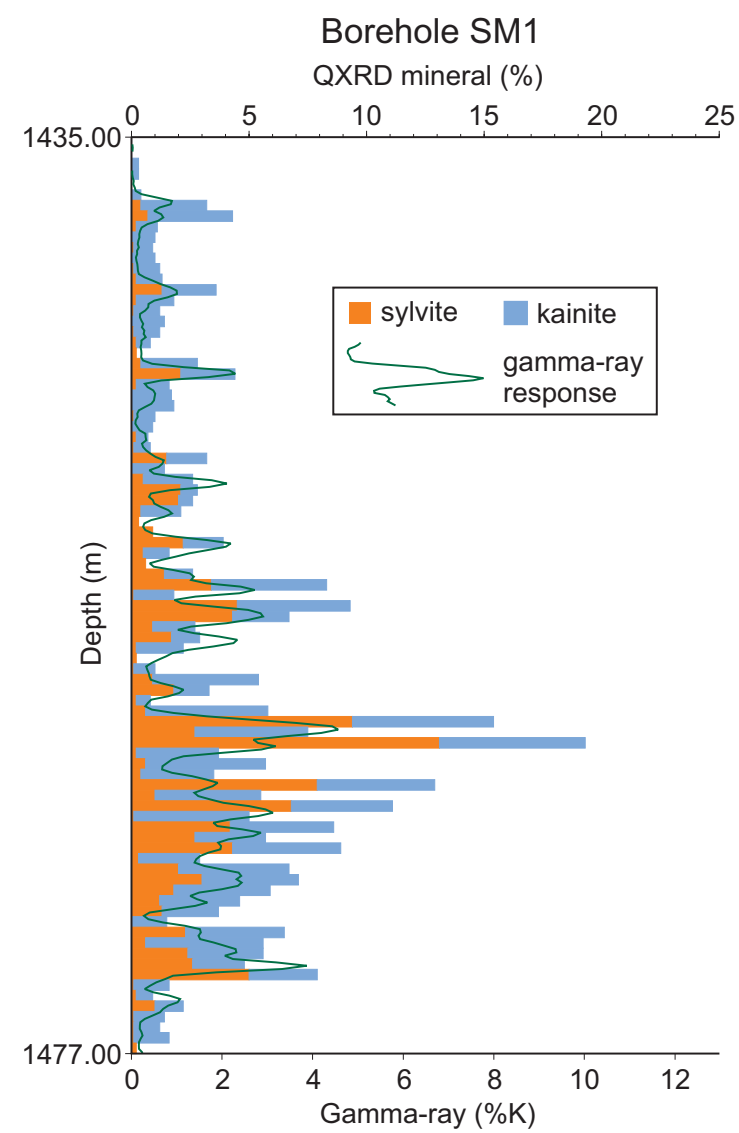

Fig. 11. Comparison of QXRD-derived sylvite- and kainite-grade (bars) with gamma-ray response (line) for the Pasture Beck seam in borehole SM1.

thin layers with high radioactivity become slightly widened and reduced in amplitude in the gamma-ray measurements that are used in the log analysis calculations.

The gamma-ray response also shows a very close correlation to the polyhalite-rich zones in borehole SM9 (Fig. 10B). However in the lower cored interval (1,544-1,568 m), between the polyhalite-rich zones, the gamma-ray log registers moderate to low responses, but no polyhalite was detected by QXRD. Instead, QXRD indicates the presence of minor quantities of kalistrontite in these zones. Since kalistrontite has a measured gamma-ray response of 303 API units compared to only 185 API units for polyhalite (Table 1), the presence of only small quantities of kalistrontite produces gamma-ray data indicative of far greater equivalent proportions of polyhalite. Similarly, in terms of geochemical data, kalistrontite contains $21.9 \% \mathrm{~K}$ compared to only $13.0 \% \mathrm{~K}$ in polyhalite, the presence of only small quantities of kalistrontite produces $\% \mathrm{~K}$ values indicative of far greater proportions of polyhalite. The gamma-ray profile for the Pasture Beck seam encountered in borehole SM1 shows a comparatively poor relationship to the QXRDdetermined sylvite (747 API units, $52.4 \% \mathrm{~K}$ ) content due to the additional presence of significant amounts of kainite (229 API units, $15.7 \%$ K; Fig. 11).

The elemental profiles produced by HH-XRFS again show a good, positive correlation with the ICP-AES and QXRD data and offer a very useful alternative where nondestruction of material is paramount, such as historic cores. However, the "spot" nature of the HH-XRFS analyses means that they produce more rapidly fluctuating geochemical profiles than the average ICP-AES and QXRD data produced from sampled intervals. Hand-held XRFS data has previously been demonstrated to produce good correlations with laboratory analyses (e.g., Potts and West, 2008) and specifically in potash projects (e.g., Eccles et al., 2009). Eccles and Murphy (2005) compared results from an early portable XRFS analyzer (Niton XL$502 S$ ) with laboratory total-digestion ICP-OES and XRFS and reported high analytical precision for selected elements $(\mathrm{Pb}$, $\mathrm{Zn}$, and $\mathrm{Fe}$ ) where samples were powdered $\left(\mathrm{r}^{2}=95-100 \%\right)$ but lower precision for spot analyses $\left(\mathrm{r}^{2}=79-89 \%\right)$. The more modern XL3t 900S HH-XRFS analyzer (Eccles et al., 2009) shows moderate to excellent correlation with $\mathrm{r}^{2}$ values for $\mathrm{K}_{2} \mathrm{O}, \mathrm{MgO}$, $\mathrm{CaO}$, and $\mathrm{S}$ of $82,96,71$, and $97 \%$, respectively, but again these were achieved on powdered samples, not spot analyses. Relative standard deviation (RSD) values based on duplicate analyses produce a measure of the relative dispersion of the values in a dataset and therefore the precision of the data. Eccles et al. (2009) measured RSDs for $\mathrm{K}_{2} \mathrm{O}$ and $\mathrm{MgO}$, which are critical for potash determination, and found average RSD values of 12 and $19 \%$, respectively. Measurements on a certified reference material (CCRMP Till-4, Lynch, 1996) produced an average value of $2.46 \% \mathrm{~K}$ and standard deviation of 0.274 compared to actual of $2.69 \% \mathrm{~K}$. Hall et al. (2014) indicated typical precision of 0.5 to $1.5 \%$ RSD for $\mathrm{K}<5 \%$, climbing to 5 to $10 \%$ at $\mathrm{K}$ levels of $\sim 0.1$ to $0.3 \%$. Eccles et al. (2009) concluded that exploration companies should use their HH-XRFS-derived potash values with caution and that future exploratory work should include laboratory analyses.

Therefore, if potash deposits are characterized using the traditional wet chemistry or gamma-ray approach (or even a combination of both), as demonstrated by the SM1 and SM9 examples, any variation in K-bearing mineralogy will lead to inaccuracies in the determined polyhalite content. The heterogeneous nature of most evaporite deposits suggests that such errors are a possibility.

Our study has not only demonstrated that QXRD data is accurate but that it also presents clear advantages over other geochemical/geophysical techniques by providing the identification of the K-bearing mineral host(s) and not simply the total available potassium. During the York Potash Ltd. investigations, polyhalite (Fordon (Evaporite) Formation) and sylvite (Boulby Potash and Sneaton Potash members) have been consistently identified as the principle K-bearing host minerals. Importantly however, further K-bearing hosts-kalistrontite, kainite, langbeinite, picromerite, syngenite and undifferentiated mica species - have all been identified in the present investigation. In addition, as evaporite deposits typically exhibit lateral changes in facies and mineralogy, our study has highlighted the importance of applying QXRD analyses across the deposit/basin to identify different concentrations of the various mineral species at stratigraphic locations and horizons.

A summary of the QXRD data generated from cored boreholes by the present study are shown on a stratigraphic basis in Figure 12.

\section{New evaporite mineral occurrences}

Significant quantities of the rare mineral kalistrontite $\left(\mathrm{K}_{2} \mathrm{Sr}\left(\mathrm{SO}_{4}\right)_{2}\right)$ were identified in the Shelf facies polyhalite 


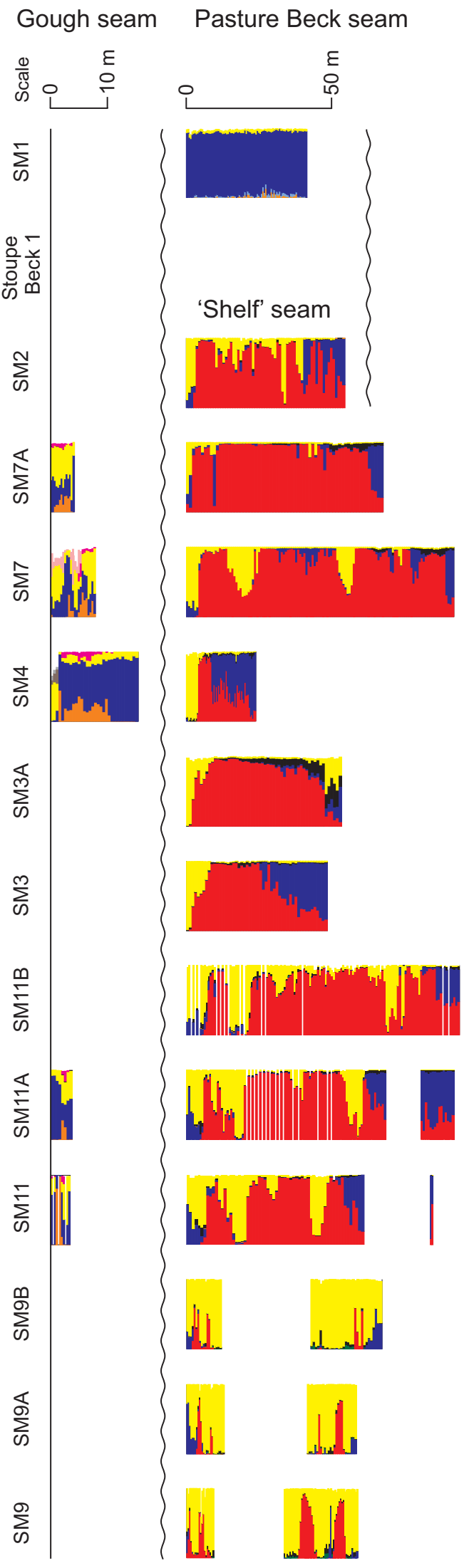

Basin seam
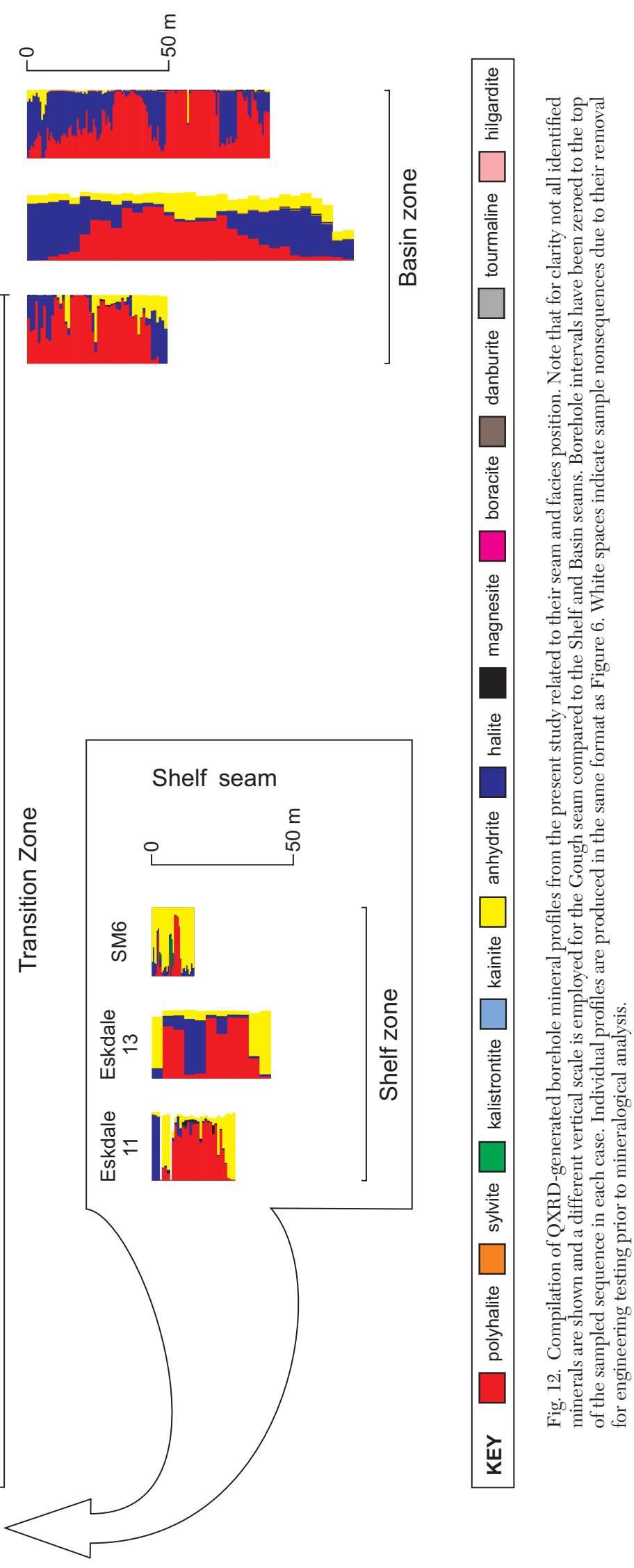
seam, intercepted by SM6 and SM9, SM9A and SM9B. This is a UK-first occurrence for the mineral which was first discovered at Alshtan, in the Ural Mountains, Russia (Voronova, 1962) and has since only been encountered at relatively few localities: Pleismar, Germany (Bader, 1967); Latium, Italy (Maras, 1979); Sichuan Province, China (Min Mo, 1987); Omongwa Pan, Namibia (Mees, 1999); and the Emet basin, Turkey (Garcia-Veigas et al., 2011). With the exception of the Italian occurrence which occurs within the Cesano geothermal field, the remaining localities are all evaporite deposits, mostly Permian in age. In most cases, kalistrontite has developed as an early diagenetic precipitate from high $\mathrm{K}$ - and $\mathrm{SO}_{4-}$ rich brines or via the alteration of precursor evaporite minerals such as sylvite or celestine. A similar genesis is possible for the kalistrontite from the North Yorkshire deposits. Here, the diagenetic process has clearly been much more powerful but selective in location. It has been identified only in two of the southernmost boreholes (adjacent sites SM6 and SM9). Recognition of the mineral when intimately mixed with anhydrite and polyhalite would be very difficult, however, from legacy core descriptions or wireline logs alone and without mineralogical or petrographical analysis, so it might be more extensive and so far unrecognized in hydrocarbon wells drilled south of SM6 and SM9. In all previous cases, kalistrontite has constituted a minor or trace mineral phase, but in North Yorkshire, we proved a thickness of $3.7 \mathrm{~m}$ at $13.05 \%$ kalistrontite, within which was an interval $1.19 \mathrm{~m}$ thick with $36.5 \%$ kalistrontite (borehole SM6). A hydrothermal source cannot be ruled out on present evidence (Smith et al., 2014).
Boron-bearing minerals such as boracite, szaibelyite, hilgardite, sulfoborite, and fluoborite have all previously been recorded from the Permian of northeastern England (e.g., Stewart, 1949; Milne, 1978; Colter and Reed, 1980). However, this work has resulted in the first recorded occurrences of howlite, danburite, and tourmaline in the English Zechstein. Further details will be included in a future petrographic paper.

The extensive, marine evaporite deposits of North America (Michigan, Saskatchewan, Utah, Colorado, New Mexico) which all contain late-stage evaporite minerals, only record trace occurrences of borate minerals (Roulston and Waugh, 1981). Borate deposits from elsewhere are most often associated with thermal springs and a volcanic origin, e.g., Andes (Muessig, 1966), California (Bowser and Dickson, 1966), Turkey (Helvaci and Firman, 1976), and Ethiopia (Holwerda and Hutchinson, 1968). Extensive, previous studies of the Permian evaporites of northern Germany and northeastern England have provided various interpretations for the source of the boron. Initially these suggested that the boron originated from seawater but more recent studies invariably involve some volcanic-driven, boron-bearing hydrothermal fluid alteration mechanism (Roulston and Waugh, 1981).

\section{Empirical model and deposit grade}

The verified QXRD polyhalite assay results were used to calculate weighted averages for the true seam thickness and for the highest grade sections (Table 5). These were used to help York Potash Ltd. to define an indicated mineral resource of $820 \mathrm{Mt}$ at a grade of $87.3 \%$ polyhalite ( 13.6 equiv $\mathrm{K}_{2} \mathrm{O} \%$ ),

Table 5. Summary of QXRD-Derived Polyhalite and Equivalent $\% \mathrm{~K}_{2} \mathrm{O}$ Assay Results

\begin{tabular}{|c|c|c|c|c|c|c|}
\hline Borehole & Thickness (m) & Polyhalite (\%) & $\mathrm{K}_{2} \mathrm{O}(\%)$ & Assay ${ }^{1}$ & Seam & Situation \\
\hline SM1 & $\begin{array}{l}23.3 \\
11.1\end{array}$ & $\begin{array}{l}95.0 \\
97.1\end{array}$ & $\begin{array}{l}14.8 \\
15.2\end{array}$ & $\begin{array}{l}\text { Weighted average } \\
\text { High grade }\end{array}$ & Basin & Basin zone \\
\hline $\mathrm{SM} 2$ & $\begin{array}{r}32.6 \\
6.6 \\
34.3 \\
6.8\end{array}$ & $\begin{array}{l}83.1 \\
95.8 \\
78.3 \\
99.2\end{array}$ & $\begin{array}{l}13.0 \\
15.0 \\
12.2 \\
15.5\end{array}$ & $\begin{array}{l}\text { Weighted average } \\
\text { High grade } \\
\text { Weighted average } \\
\text { High grade }\end{array}$ & $\begin{array}{l}\text { Shelf } \\
\text { Basin }\end{array}$ & Transition zone \\
\hline $\begin{array}{l}\text { SM3 } \\
\text { SM3A }\end{array}$ & $\begin{array}{l}25.2 \\
16.2 \\
46.9 \\
23.0\end{array}$ & $\begin{array}{l}87.5 \\
95.9 \\
83.0 \\
93.0\end{array}$ & $\begin{array}{l}13.7 \\
15.0 \\
13.0 \\
14.5\end{array}$ & $\begin{array}{l}\text { Weighted average } \\
\text { High grade } \\
\text { Weighted average } \\
\text { High grade }\end{array}$ & Shelf & Transition zone \\
\hline $\mathrm{SM} 4$ & 5.1 & 89.4 & 14.0 & High grade & Shelf & Transition zone \\
\hline SM6 & 2.2 & 85.6 & 13.4 & High grade & Shelf & Shelf zone \\
\hline $\begin{array}{l}\text { SM7 } \\
\text { SM7A }\end{array}$ & $\begin{array}{l}54.0 \\
58.7\end{array}$ & $\begin{array}{l}88.4 \\
92.4\end{array}$ & $\begin{array}{l}13.8 \\
14.4\end{array}$ & Weighted average & Shelf & Transition zone \\
\hline $\begin{array}{l}\text { SM9 } \\
\text { SM9A } \\
\text { SM9B }\end{array}$ & $\begin{array}{l}7.3 \\
2.5 \\
2.3\end{array}$ & $\begin{array}{l}82.8 \\
76.7 \\
42.0\end{array}$ & $\begin{array}{r}12.9 \\
12.0 \\
6.6\end{array}$ & High grade & Shelf & Shelf zone \\
\hline SM11 & $\begin{array}{l}45.9 \\
26.6\end{array}$ & $\begin{array}{l}67.8 \\
87.8\end{array}$ & $\begin{array}{l}10.6 \\
13.7\end{array}$ & $\begin{array}{l}\text { Weighted average } \\
\text { High grade }\end{array}$ & Shelf & Transition zone \\
\hline SM11A & $\begin{array}{l}57.1 \\
27.0\end{array}$ & $\begin{array}{l}70.2 \\
93.0\end{array}$ & $\begin{array}{l}11.0 \\
14.5\end{array}$ & $\begin{array}{l}\text { Weighted average } \\
\text { High grade }\end{array}$ & & \\
\hline SM11B & $\begin{array}{l}72.4 \\
58.0\end{array}$ & $\begin{array}{l}75.4 \\
88.0\end{array}$ & $\begin{array}{l}11.8 \\
13.7\end{array}$ & $\begin{array}{l}\text { Weighted average } \\
\text { High grade }\end{array}$ & & \\
\hline
\end{tabular}

1'Assay is given as the weighted average for the quoted true seam thickness, within which the high grade section occurs 
and inferred resource of $1,840 \mathrm{Mt}$ at $85.2 \%$ polyhalite (13.3 equiv $\mathrm{K}_{2} \mathrm{O} \%$ ), reported in compliance with the JORC Code (JORC, 2012).

The mineralogical data were also used to produce a descriptive, empirical model for the deposit (Fig. 13). As discussed previously, two polyhalite seams, the Shelf and the Basin seams have been identified during the exploration program, the correlation of which remains ambiguous.

\section{Conclusions}

This study, together with an increasing body of research, suggests that quantitative XRD now offers an accurate, credible, and economic methodology for the mineralogical characterization and grade determination of mineral deposits. The North Yorkshire potash characterization project detailed here has demonstrated the advantages that XRD analyses offer over the more traditional gamma-ray and geochemical approaches by providing the quantification of the K-bearing mineral hosts and not simply the total available potassium.

Importantly this study has also highlighted possible deficiencies regarding geochemical analyses and geophysical interpretations that may have implications for previous potash investigations. Reliance on single, wet chemical techniques or geophysical logs may have underestimated the $\mathrm{K}$ mineral content of samples. As is the case with almost all geologic investigations, this study has proved that corroborative data from a range of different techniques help provide the most satisfactory outcome.

We have consistently identified polyhalite (Fordon (Evaporite) Formation) and sylvite (Boulby Potash and Sneaton Potash members) as the principal K-bearing host minerals in the Permian evaporite succession of North Yorkshire. However, further K-bearing hosts-kalistrontite (a UK-first occurrence), kainite, langbeinite, picromerite, syngenite, and undifferentiated mica species-have also been identified. Although boron-bearing minerals have previously been recorded from the locality, the study has also recorded the first occurrences of howlite, danburite, and tourmaline in the English Zechstein.

Application of the QXRD-led characterization program across the evaporitic basin has also helped to produce a descriptive, empirical model for the deposit, identifying different concentrations of the various mineral species at different stratigraphic locations and horizons. Two polyhalite seams, the Shelf seam (shallow-water facies) and the Basin seam (deeper-water facies) have been identified during the exploration program, the correlation of which remains ambiguous. The York Potash Ltd. exploration area straddles the margin of this original basin, with boreholes situated on the Shelf, in the Basin, and some on the ramp in a Transition zone between the two. Two additional EZ2, sylvite-bearing bittern salt horizons have been named the Pasture Beck and Gough seams after the boreholes in which they were first encountered.

The generated QXRD dataset has enabled identification of a mineral inventory of $2,660 \mathrm{Mt}$ at $85.7 \%$ polyhalite (13.4 equiv $\% \mathrm{~K}_{2} \mathrm{O}$ ) in York Potash Ltd.'s area, that itself forms only a small part of the Fordon (Evaporite) Formation polyhalite deposit. These observations support the claim that the Permian succession of North Yorkshire supports the world's richest-known deposit of polyhalite. Planning applications for a new mine (sited at Dove's Nest, borehole SM11, Fig. 1) and
W

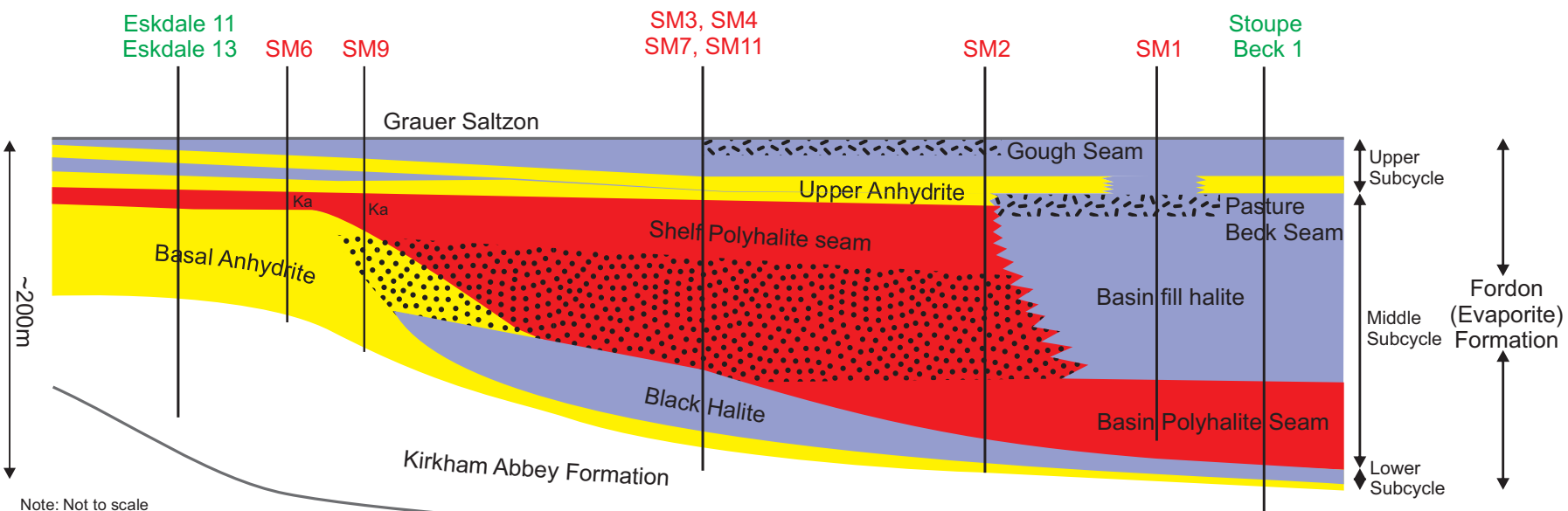

\section{E}

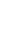

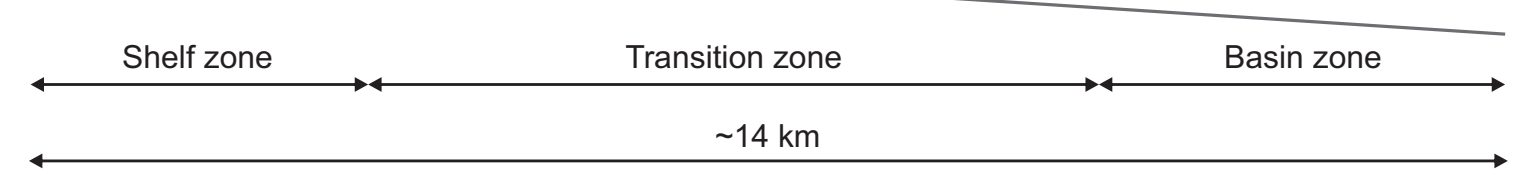

\begin{tabular}{|c|c|c|c|c|c|}
\hline Polyhalite & Halite & Anhydrite & Limestone & $\because \because=$ & Sylvite \\
\hline Sulphatic & hydritic) & \multicolumn{2}{|c|}{ Sulphatic halite (polyhalitic) } & Ka & Kalistrontite \\
\hline
\end{tabular}

Fig. 13. Conceptual geologic model for the Fordon (Evaporite) Formation in the York Potash Ltd AOI. 
mineral conveyor tunnel to Teesport (Fig. 1) have now been approved by the North York Moors National Park Authority and Redcar and Cleveland Borough Council.

\section{Acknowledgments}

The characterization of the York Potash Ltd. deposits outlined in this paper has involved the work of an extensive project team at the British Geological Survey (BGS), FWS Consultants, and York Potash Ltd. and their efforts are gratefully acknowledged. However, the authors would particularly like to thank Jeremy Dearlove (formerly FWS, now at Northumbrian Water Ltd.), Scott Renshaw and team (BGS) for core slabbing, inspection facilities, and curation, Paul Witney (BGS) for core photography, and Kevin Barker and team (BGS) for sample crushing and milling. PANalytical (Nottingham) are thanked for the laboratory XRFS analyses. The authors would also like to thank York Potash Ltd. for permission to publish this paper. We are grateful to John Powell, Andrew Bloodworth (BGS), and journal reviewers A. Dave Mackintosh and Susan Lomas for their insightful reviews of earlier versions of the manuscript. SK, DW, IM, CM and CG publish with the permission of the Executive Director, British Geological Survey (NERC).

\section{REFERENCES}

Adams, S.S., and Hite, R.J., 1983, Potash, in Lefond, S.J., ed, Industrial minerals and rocks, $5^{\text {th }}$ ed: New York, American Institute of Mining, Metallurgical, and Petroleum Engineers, p. 1049-1077.

Alger, R.P., and Crain, E.R., 1966, Defining evaporite deposits with electrical well logs: Northern Ohio Geological Society, Symposium on Salt, $2^{\text {nd }}$, Cleveland, Ohio, 1965, Transactions, v. 2, p. 116-130.

Allen, D., Lyders, M., Schwandt, M., Johnson, R., Mathews, W., French, K., and Daitch, P. 2013. Quantitative Rietveld XRD mineralogy of copper and molybdenum ore products [abs.]: Accuracy in Powder Diffraction APD-IV, http://www.nist.gov/mml/upload/APD-IV_Abstracts.pdf.

Bader, E., 1967, The genesis of kalistrontite in the Stassfurt salt bed in the Pleismar 2/64 boring: Chemie der Erde, v. 26, p. 304-321.

Barbarick, K.A., 1989, Polyhalite as a potassium fertilizer: Fort Collins, CO, Colorado State University Agricultural Station, Technical Bulletin TB89-2.

Belknap, W.B., Dewan, J.T., Kirkpatrick, C.V., Mott, W.E., Pearson, A.J., and Rabson, W.R., 1959, API calibration facility for nuclear logs: American Petroleum Institute, Drilling and Production Practice, p. 289-317 (summary of RP33; reprinted in SPWLA Reprint Volume on Gamma Ray, Neutron, and Density Logging, Mar. 1978).

Bish, D.L., and Post, J.E., 1993, Quantitative mineralogical analysis using the Rietveld full-pattern fitting method: American Mineralogist, v. 78, p. 932-940.

Bish, D.L., and Reynolds, R.C., 1989, Sample preparation for X-ray diffraction: Reviews in Mineralogy, v. 20, p. 73-100.

Bish, D.L., and Scanlan, M.K., 2006, The hydration and dehydration of hydrous mixed-cation sulphates [abs.]: Lunar and Planetary Science, XXXVII [CD-ROM], Abstract 1011.

Bowser, C.J., and Dickson, F.W., 1966, Chemical zonation of the borates of Kramer, California: Northern Ohio Geological Society, Symposium on Salt, $2^{\text {nd }}$, Cleveland, Ohio, 1965, Transactions, v. 2, p. 122-132.

Breward, N., Kemp, S.J., Ambrose, K., Powell, J.H., Morigi, A., and Wagner, D., 2015, Anomalous enrichment of molybdenum and associated metals in Lower Jurassic (Lias Group) black shales of central England, as revealed by systematic geochemical surveys: Proceedings of the Geological Association, http://dx.doi.org/10.1016/j.pgeola.2015.03.007

British Geological Survey, 2011, Mineral planning factsheet: Potash [Online]: http://www.bgs.ac.uk/mineralsuk/planning/mineralPlanningFactsheets. html.

Colter, V.S., and Reed, G.E., 1980, Zechstein 2 Fordon evaporites of the Altwick no. 1 borehole, surrounding areas of NE England and the adjacent southern North Sea: Contributions to Sedimentology, v. 9, p. 115-129.

Crain, E.R., and Anderson, W.B., 1966, Quantitative log evaluation of the Prairie evaporite formation in Saskatchewan: Journal of Canada Petrology and Technology, v. 5, p. 45-152.
Crowfoot, D., Bunn, C.W., Rogers-Low, B.W., and Turner-Jones, A., 1949 $\mathrm{X}$-ray crystallographic investigation of the structure of penicillin, in Clarke, H.T., Johnson, J.R., and Robinson, R., eds., Chemistry of penicillin: Princeton, NJ, Princeton University Press, p. 310-367.

Crowl, W.J., Hulse, D.E., Lane, T.A., and Malhotra, D., 2011, Technical report on the polyhalite resources and updated preliminary economic assessment of the Ochoa project, Lea County, southeast New Mexico: Gus tavson Associates Technical Report NI 43-101 for IC Potash Corp., http:// www.icpotash.com/_resources/pdf/ICP_PEA.pdf.

Doornenbal, H., and Stevenson, A., 2010, Petroleum geological atlas of the southern Permian Basin Area: Houten, Netherlands, EAGE Publications, $342 \mathrm{p}$.

Degen, T., Sadki, M., Bron, E., König, U., and Nénert, G., 2014, The HighScore suite: Powder Diffraction, v. 29, S13-S18, doi:10.1017/S0885715614000840.

Edmundson, H., and Raymer, L.L., 1979, Radioactive logging parameters for common minerals: Log Analyst, v. 20, is. 5, p. 38-47.

Eccles, D.R., and Murphy, E., 2005, Comparison of field-portable X-ray fluorescence analyzer and conventional geochemical analysis: Alberta Energy and Utilities Board, EUB/AGS Geo-Note 2004-04.

Eccles, D.R., Al-Souqi, M., Grattan, K., and Dufresne, M.B., 2009, Preliminary investigation of potash potential in Alberta: Energy Resources Conservation Board/Alberta Geological Survey Open File Report 2009-20. http:// www.ags.gov.ab.ca/publications/OFR/PDF/OFR_2009_20.pdf.

Eckert, M., 2012, Max von Laue and the discovery of X-ray diffraction in 1912: Annalen der Physik, v. 524(5), p. A83-A85.

Emons, H.-H., Ziegenbalg, G., Naumann, R., and Paulik, F., 1990, Thermal decomposition of the magnesium sulphate hydrates under quasi-isothermal and quasi-isobaric conditions: Journal of Thermal Analysis, v. 36, p. 1265-1279.

Fischer, S., Voigt, W., and Kohnke, K., 1996, The thermal decomposition of polyhalite $\mathrm{K}_{2} \mathrm{SO}_{4} \cdot \mathrm{MgSO}_{4} \cdot 2 \mathrm{CaSO}_{4} \cdot 2 \mathrm{H}_{2} \mathrm{O}$ : Crystal Research and Technology, v. 31, p. 87-92.

Ford, M.E., Baines, A.J., and Tarron, R.D., 1974, Log analysis by linear programming - an application to the exploration for salt cavity storage locations: Society of Professional Well Log Analysts, Transactions B, 13 p.

García-Veigas, I., Rosell, L., Orti, F., Gündoğan, I., and Helvaci, C., 2011, Mineralogy, diagenesis and hydrochemical evolution in a probertite-glauberite-halite saline lake (Miocene, Emet basin, Turkey): Chemical Geology, v. 280 , p. 352-364.

Hall, G.E.M., Bonham-Carter, G.F., and Buchar, A., 2014, Evaluation of portable X-ray fluorescence ( $\mathrm{pXRF}$ ) in exploration and mining: Phase 1 , control reference materials: Geochemistry: Exploration, Environment, Analysis, v. 14, p. 99-123.

Hardy, M.P., Halabura, S.P., Shewfelt, D., and Hambley, D.F., 2010, Potash reserve assessment for subsurface mineral permit KP289, Saskatchewan: Agapito Associates, Colorado, Technical Report 2010, 193 p.

Helvaci, C., and Firman, R.J., 1976, Geological setting and mineralogy of Emet borate deposits, Turkey: Institution for Mining and Metallurgy, Transactions, v. 85, p. B142-B152.

Hestnes, K.H., and Sørensen, B.E., 2012, Evaluation of quantitative X-ray diffraction for possible use in the quality control of granitic pegmatite in mineral production: Minerals Engineering, v. 39, p. 239-247.

Hettipathirana, T., Grey, N., and Naidu, R., 2003, Elimination of analytical error due to the use of catch weights with loss-eliminated alphas in X-ray fluorescence spectrometric analysis of limestone using borate fusions: Spectrochimica Acta B., v. 58, p. 85-95.

Hillier, S., 1999, Use of an air-brush to spray dry samples for X-ray powder diffraction: Clay Minerals, v. 34, p. 127-135.

Holwerda, J.G., and Hutchinson, R.W., 1968, Potash bearing evaporites in the Danakil area, Ethiopia: Economic Geology, v. 63, p. 124-150.

Humphreys, B., and Lott, G.K., 1990, An investigation into nuclear log responses of North Sea Jurassic sandstones using mineralogical analysis: Geological Society, London, Special Publication 48, p. 223-240.

International Centre for Diffraction Data (ICDD), 2014, PDF-4+ 2014 (database), Soorya Kabekkodu, ed.: Newtown Square, PA, International Centre for Diffraction Data.

Inorganic Crystal Structure Database (ICSD), 2014, ICSD is available at FIZ Karlsruhe at http://www.fiz-karlsruhe.de/icsd.html or http://icsdweb. fiz-karlsruhe.de. (Currently the ICSD database contains more than 173,000 entries of fully determined inorganic crystal structures).

International Fertilizer Industry Association (IFA), 2009, Recommended best practice for the analysis of potassium content in potassium chloride (KCL) fertilizers: Paris, France, www.fertilizer.org. 
JORC, 2012, Australasian code for reporting of exploration results, mineral resources and ore reserves (JORC code): Available from: http://www.jorc. org (the Joint Ore Reserves Committee of the Australasian Institute of Mining and Metallurgy, Australian Institute of Geoscientists and Minerals Council of Australia).

Knorr, K., 2012, Use of XRD in the iron ore business: Bruker First Newsletter, https://www.bruker.com/applications/material-science/mining-minerals/latest-literature.html.

Kruger, N., 2013, The Potash Members of the Prairie Formation in North Dakota: North Dakota Geological Survey Report of Investigations 113.

Lager, G.A., Armbruster, Th., Rotella, F.J., Jorgensen, J.D., and Hinks, D.G., 1984, A crystallographic study of the low-temperature dehydration products of gypsum, $\mathrm{CaSO}_{4} \cdot 2 \mathrm{H}_{2} \mathrm{O}$, hemihydrate $\mathrm{CaSO}_{4} \cdot 0.50 \mathrm{H}_{2} \mathrm{O}$, and $\gamma-\mathrm{CaSO}_{4}$ : American Mineralogist, v. 69, p. 910-918.

Lomas, S., 2008, Technical report for a resource estimation on the Burr project, Athabasca Potash Inc., Saskatchewan, Canada: AMEC Technical Report NI 43-101 for Athabasca Potash Inc. http://www.sedar.com/GetFile. do?lang $=$ ENanddocClass $=24$ andissuerNo $=00026182$ andfileName $=/ \mathrm{csfs}-$ prod/data93/filings/01343208/00000001/i\%3A\%5C1SEDAR\%5C554637\% 5CTechnicalReport\%5CTechnicalReport.pdf

Loubser, M., Strydom, C., and Potgieter, H., 2004, A thermogravimetric analysis study of volatilization of flux mixtures used in XRF sample preparation: X-ray Spectrometry, v. 33, p. 212-215.

Lynch, J., 1996, Provisional elemental values for four new geochemical soil and till reference materials, TILL-1, TILL-2, TILL-3 and TILL-4: Geostandards Newsletter, no. 20 , p. 277-287.

MacKenzie, R.C., ed., 1972, Differential thermal analysis: London, Academic Press, v. 2.

Madsen, I.C., Scarlett, N.V.Y., Lachlan Cranswick, M.D., and Lwin, T., 2001, Outcomes of the International Union of Crystallography Commission on Powder Diffraction Round Robin on quantitative phase analysis: samples 1a to 1h: Journal of Applied Crystallography, v. 34, p. 409-426.

Marincea, S., 2001, New data on szaibelyite from the type locality, Băiţa Bihor, Romania: Canadian Mineralogist, v. 39, p. 111-127.

Maras, A., 1979, Studi sui minerali del Lazio: la kalistrontite di Cesano: Periodico di Mineralogia, v. 48, p. 195-203.

Mees, F., 1999, Distribution patterns of gypsum and kalistrontite in a dry lake basin of the southwestern Kalahari (Omongwa pan, Namibia): Earth Surface Processes and Landforms, v. 24, p. 731-744.

Milne, J.K., 1978, The potash deposits and their associates in the area of the Boulby mine, Cleveland: PhD thesis, University of Edinburgh, 368 p.

Min Mo, 1987, The first discovery of kalistrontite in China and its significance in search for potash deposits: Acta Mineralogica Sinica, v. 7, p. 154-158.

Morgan, J.J., 1921, New method for determination of potassium in silicates: Journal of Industrial and Engineering Chemistry, v. 13, p. 225-227.

Muessig, S., 1966, Recent South American borate deposits: Northern Ohio Geological Society, Symposium on Salt, $2^{\text {nd }}$, Cleveland, Ohio, 1965, Transactions, v. 1, p. 151-159.

Nelson, P.H., 2007, Evaluation of potash grade from gamma-ray logs: U.S. Geological Survey Open-File Report 2007-1292.

O'Connor, B.H., and Chang, W.J., 1986, The amorphous character and particle size distribution of powders produced with the micronizing mill for quantitative X-ray powder diffractometry: X-ray Spectrometry, v. 15, p. 267-270.

Omotoso, O., McCarty, D.K., Hillier, S., and Kleeburg, R., 2006, Some successful approaches to quantitative mineral analysis as revealed by the 3 rd Reynolds Cup contest: Clays and Clay Minerals, v. 54, p. 748-760.

Peryt, T.M., Pierre, C., and Gryniv, S.P., 1998, Origin of polyhalite deposits in Zechstein (Upper Permian) Zdrada platform (northern Poland): Sedimentology, v. 45, p. 565-578.

Potts P.J., and West, M., 2008, Portable X-ray fluorescence spectrometry. Capabilities in in-situ analysis: Cambridge, RSC Publishing.

Prud'homme, M., and Krukowski, S.T., 2006, Potash, in Kogel, J.E., ed., Industrial minerals and rocks: Commodities, markets, and uses: Society for Mining, Metallurgy and Exploration, p. 723-741.

Rauche, H., and van der Klauw, S.N.G.C. 2007, Resource estimate for the Makola exploration permit area, Kouilou region, Republic of Congo: Ercosplan Technical Report EGB 04-037 for MagMinerals Inc., http://www. magindustries.com/cmsdocs/Technical\%20Reports/04-037_NI-43-101_ Resource_Report.pdf

2010, Technical report and current resource estimate for the Danakil potash deposit, Afar State, Ethiopia: Ercosplan Technical Report EGB 08-024 for Allana Potash (Resources) Inc. https://www.otciq.com/otciq/ajax/ showFinancialReportById.pdf?id=98601
Raven, M.D., and Self, P., 2013, Accuracy in quantitative phase analysis of complex mineral assemblages: A decade of Reynolds Cup round robins: Accuracy in Powder Diffraction APD-IV, http://www.nist.gov/mml/ upload/6-2_MRaven_APD_IV.pdf

Rider, M., 1990, Gamma-ray log shape used as a facies indicator: Critical analysis of an oversimplified method: Geological Society of London Special Publication 48, p. 27-37.

Rietveld, H., 1969, A profile refinement method for nuclear and magnetic structures: Journal of Applied Crystallography, v. 2, p. 65-71.

Roulston, B.V., and Waugh, D.C.E., 1981, A borate mineral assemblage from the Penobsquis and Salt Springs evaporite deposits of southern New Brunswick: Canadian Mineralogist, v. 19, p. 291-301.

Santini, T.C., 2015, Application of the Rietveld refinement method for quantification of mineral concentrations in bauxite residues (alumina refining tailings): International Journal of Mineral Processing, (in press), doi:10.1016/j. minpro.2015.04.004

Saskatchewan Research Council, Saskatoon, 2015, http://www.src.sk.ca resource\%20files/geoanalytical\%20laboratories\%20potash\%20xploration\%20package\%20fact\%20sheet.pdf. Accessed March 2015.

Schlumberger, 2004, Spectral gamma ray tools specification sheet: http:// www.slb.com/ /media/Files/evaluation/product sheets/wireline_open hole/petrophysics/gamma/sgrt.pdf. Accessed 28 May 2015

Serra, O., and Sulpice, L., 1975, Sedimentological analysis of shale-sand series from well logs: Society of Professional Well Log Analysts, Annual Logging Symposium, $16^{\text {th }}$, Transactions, Paper $\mathrm{W}$.

Smith, D.B., 1989, The Late Permian palaeogeography of north-east England: Proceedings of the Yorkshire Geological Society, v. 47, p. 285-312.

Smith, D.B., Harwood, G.M., Pattison, J. and Pettigrew, T.H., 1986, A revised nomenclature for Upper Permian strata in eastern England, in Harwood, G.M., and Smith, D.B., eds., The English Zechstein and related topics: Geological Society of London Special Publication no 22

Smith, F.W., Dearlove, J.P.L., Kemp S.J., Bell, C.P., Milne, C.J., and Pottas, T.L., 2014, Potash-recent exploration developments in North Yorkshire: Extractive Industry Geology Conferences Ltd. Conference, 17 th Edge Hill University, September 5-8, 2012, Proceedings, p. 45-50.

Snyder, R.L., and Bish, D.L., 1989, Quantitative analysis: Mineralogical Society of America, v. 20, p. 101-144.

SRK Consulting Ltd., 2011, Technical report on exploration potential, Holbrook basin potash project, Navajo County, Arizona: SRK Consulting (U.S.), Inc. Technical Report NI 43-101 for Passport Potash Inc., http:// www.passportpotash.com/pdf/SRK.pdf

2014, An independent report on the potential for polyhalite exploration in North Yorkshire, England, with particular reference to the York potash project: http://planning.northyorkmoors.org.uk/MVM.DMS/Planning\%20 Application/811000/811019/ac\%20Alternative\%20Sites\%20Assessment\%20Appendices\%20Part\%2002.pdf.

SRK Consulting Ltd. et al., 2012, Technical report Sintoukola potash project, Republic of Congo: SRK Consulting (U.S.), Inc, CSA Global Pty Ltd, Egis and Amec Technical Report NI 43-101 for Elemental Minerals Limited, http://www.elementalminerals.com/upload/documents/sintoukola_ni_43101_tr_pfs_340100_020_rev066_20120920.pdf.

Stewart, F.H., 1949, The petrology of the evaporites of the Eskdale no. 2 boring: East Yorkshire: I. The lower evaporite bed: Mineralogical Magazine, v. 28 , p. $621-675$.

1963, The Permian lower evaporites of Fordon in Yorkshire: Proceedings of the Yorkshire Geological Society, v. 34, p. 1-44.

Stutzman, P., 2005, Powder diffraction analysis of hydraulic cements: ASTM Rietveld round-robin results on precision: Powder Diffraction, v. 20 p. $97-100$.

Tixier, M.P., and Alger, P.R., 1970, Log evaluation of non-metallic mineral deposits: Geophysics, v. 35, p. 124-142.

Todor, D.N., 1976, The thermal analysis of minerals: Tunbridge Wells, UK, Abacus Press, $256 \mathrm{p}$

Voronova, M.L., 1962, Kalistrontite, a new potassium strontium sulphate Zapiski Vsesoyuznogo Mineralogicheskogo Obshchestva, v. 91, p. 712-717.

Watson, J.D., and Crick, F.H.C., 1953, A structure for deoxyribose nucleic acid: Nature, v. 171, p. 737-738.

Yang, C., and Chi, G., 2013, Quantitative evaluation of potash grade and mineralogy based on geophysical well-log analysis: Preliminary study of the Prairie evaporite in Saskatchewan: Saskatchewan Geological Survey, Saskatchewan Ministry of Economy Miscellaneous Report 2013-4.1, Paper A-1, 10 p. 


\section{APPENDIX}

\section{Technical Methodologies}

\section{Hand-held X-ray fluorescence spectrometry}

Selected sections of slabbed core from SM1 were profiled using a nondestructive Niton XLt 793 hand-held energy dispersive-X-ray fluorescence spectrometer (HH-XRFS) to determine $\mathrm{K}$ and $\mathrm{Ca}$ content and thereby an indication of the presence of elevated levels of sylvite and polyhalite.

The Niton XLt 793 HH-XRFS is small, robust, and moderately lightweight, making it suitable for use in the field or in a core observation laboratory. It uses a miniature $\mathrm{X}$-ray tube (35 kV with Ag anode) for production of primary radiation and induces secondary fluorescence from the elements within the sample detected by a silicon PIN diode detector.

Analysis was achieved by placing the exposure window of the analyzer in direct contact with flat-core surfaces. Optimal excitation conditions without saturating the detector were selected resulting in an analysis time of $30 \mathrm{~s} / \mathrm{sample}$.

The supplied, soil application (intended for use where the elements with atomic number higher than $\mathrm{Fe}$ are expected to be present at levels less than 1,000 ppm) corrects for sample matrix effects by the Compton normalization method and is ideally suited to the determination of $\mathrm{Ca}$ and $\mathrm{K}$ concentrations in sample matrices dominated by these relatively light elements.

The reported values are known to systematically underestimate absolute concentration and were therefore regarded as indicative; but the relative concentrations can be regarded as internally consistent for comparison purposes. Initial assessment of measurement errors indicates a detection limit for $\mathrm{K}$ of approximately $0.2 \%$ with a limit of quantification of approximately $0.7 \%$ and a detection limit for $\mathrm{Ca}$ of $0.1 \%$ with a limit of quantification of approximately $0.3 \%$.

Quality control samples (milled and homogenized polyhalite material covering the ranges of expected $\mathrm{K}$ and $\mathrm{Ca}$ concentrations) were analyzed before and after the analysis of the core material on each day of analysis; derived concentrations were compared against previously acquired data using QC charts to demonstrate compliant spectrometer performance. Typically, relative standard deviations (RSD) for K and Ca in polyhalite materials were better than $4 \%$.

While providing confidence for the first borehole that highgrade mineralization was present, and providing a useful confirmation of wireline interpretations, the method was not applied to subsequent boreholes. The wireline and detailed geologic logs were found to be adequate to guide sampling intervals.

\section{Inductively coupled plasma-atomic emission spectroscopy (ICP-AES)}

Aqueous dissolution (sylvite-bearing samples): Approximately $2 \mathrm{~g}$ homogenized sample was weighed into a polypropylene tube and $50 \mathrm{ml}$ deionized water added. The mixture was then shaken overnight to achieve equilibrium followed by centrifugation at 3,000 rpm for $10 \mathrm{~min}$. The supernatant was decanted for ion chromatography, alkalinity measurement, and ICPAES. The residue was washed onto a preweighed filter, dried, and stored for reference.
Lithium metaborate fusion (polyhalite-bearing samples): A fusion method was preferred to a mixed acid digestion for the preparation of insoluble samples. Approximately $0.2 \mathrm{~g}$ homogenized sample was weighed into a platinum crucible and mixed with approximately $0.8 \mathrm{~g}$ lithium metaborate. In the early stages of the project a gradual fusion temperature profile was used whereby the crucibles were placed in a preheated furnace $\left(50^{\circ} \mathrm{C}\right)$, which was ramped up to $120^{\circ} \mathrm{C}$ and held for $10 \mathrm{~min}$, then further ramped up to $950^{\circ} \mathrm{C}$ and held for $30 \mathrm{~min}$ before being allowed to cool to ambient temperature. Following assessment of the early results (see discussion) the fusion method was amended to incorporate a faster, "flash" fusion where the samples were exposed to high temperatures for a much shorter time. For the later work, crucibles were placed in a preheated furnace at $1,000^{\circ} \mathrm{C}$ for $10 \mathrm{~min}$, before being removed and allowed to cool. The cooled crucibles were placed into bottles containing $50 \mathrm{ml}$ deionized water and $5 \mathrm{ml}$ nitric acid and were shaken overnight. The following day, a further $45 \mathrm{ml}$ deionized water was added to the vessel and shaken by hand. A $30 \mathrm{ml}$ aliquot was then removed for analysis by ICP-AES. Each fusion batch included a process blank, two of six possible reference samples, and a duplicate fusion of an "unknown" sample.

Both aqueous dissolution and fusion-prepared samples were analyzed on a Perkin-Elmer Optima 7300DV ICP-AES which was calibrated daily to cover the range of concentrations anticipated. Prior to this work, the potential spectral interferences, suppression or enhancement of the plasma associated with high concentrations of lithium, potassium, and sodium were tested. Calibration standards, analytical blanks, and quality controls were matrix matched with lithium metaborate to compensate for the potential signal enhancement of lithium ions in the plasma. Samples were diluted with $1 \%$ nitric acid ten-fold to accommodate the upper calibration limit of the ICP-AES method. Once diluted, samples were shaken to ensure complete homogenization due to the difference in matrix between the sample and diluent.

\section{Thermal analysis}

Thermal analysis is a term for a suite of techniques that involve measuring and interpreting a range of properties that occur when a sample is subjected to a controlled heating program under different gaseous environments. In this case, samples were analyzed using thermogravimetry (TGA), simultaneously measuring the mass change, thermal changes (exothermic or endothermic, DTA), together with characterization of any evolved gases (EGA).

For this, approximately 50-mg portions of ball-milled samples were heated in $150-\mu \mathrm{l}$ platinum crucibles from $25^{\circ}$ to $420^{\circ} \mathrm{C}$ in a Mettler-Toledo TGA/SDTA851e system coupled to a Pfeiffer Vacuum ThermoStar mass spectrometer. The equipment was controlled and thermal analysis data analyzed using the Mettler-Toledo STARe software suite. A gas flow of $80 \mathrm{ml} / \mathrm{min} \mathrm{N}_{2}$ and a heating rate of $10^{\circ} \mathrm{C} / \mathrm{min}$ were selected.

\section{$X$-ray fluorescence spectrometry (XRFS)}

Fused beads were prepared by fusing a mass of ignited sample with a mass equivalent to $0.9000 \mathrm{~g}$ of unignited sample 
plus $9.000 \mathrm{~g}$ flux $\left(66 / 34 \mathrm{Li}_{2} \mathrm{~B}_{4} \mathrm{O}_{7}\right.$ and $\left.\mathrm{LiBO}_{2}\right)$ at $1,050^{\circ} \mathrm{C}$. To account for any inherent moisture and noncrystalline water, samples for XRFS were first dried at $105^{\circ} \mathrm{C}$.

The fused beads were analyzed using a PANalytical Axios mAX sequential, fully automatic wavelength-dispersive X-ray fluorescence spectrometer, fitted with a $60-\mathrm{kV}$ generator and 4-kW rhodium (super sharp) end-window X-ray tube. Background factors, where applicable, were calculated by either angular difference $(2 \theta)$ or from regression values from "highpurity" single oxide standards. Line-overlap factors were calculated from "high-purity" oxide standards of the interfering analyte on regression. The PANalytical calibration algorithm was used to fit calibration curves, deriving calibration constants for slope and concentration intercept. Interelement effects were corrected by fundamental parameter (FP) coefficients, calculated by the PANalytical fundamental parameter method. All backgrounds and peaks were corrected for instrument drift using two external ratio monitors. Drift correction intensities from the monitors were stored on hard disc and used to monitor instrumental stability and detect machine faults. The calibrations were validated by analysis of a wide range of reference materials. 